\title{
Siteless Survey and Intensive Data Collection in an Artifact-rich Environment: Case Studies from the Eastern Corinthia, Greece
}

\author{
William R. Caraher ${ }^{1}$, Dimitri Nakassis ${ }^{2}$ and David K. Pettegrew ${ }^{3}$ \\ ${ }^{1}$ Department of History, The University of North Dakota, Box 8096, Grand Forks, ND 58202, USA \\ E-mail: william.caraher@und.edu \\ ${ }^{2}$ Department of Classical Studies, Trinity University, 1 Trinity Place, San Antonio, TX 78212, USA \\ E-mail: dimitri.nakassis@trinity.edu \\ ${ }^{3}$ Department of History, Messiah College, 1 College Avenue, Grantham, PA 17027, USA \\ E-mail: dpettegrew@messiah.edu
}

\begin{abstract}
Archaeological survey in the eastern Mediterranean has become increasingly intensive over the last 20 years, producing greater and more diverse data for smaller units of space. While complex, siteless data sets have allowed more sophisticated reconstructions of natural and cultural regional histories, the employment of more intensive methods has refocused the scope of Mediterranean surveys from region to 'micro-region'. Such increasingly myopic approaches have been criticized for their failure to address research questions framed by a large-scale, regional perspective and the analytical categories of 'settlement' and 'site'. This paper uses results from a survey in southern Greece to show how artifact-based approaches make valuable contributions to 'big-picture' historical and archaeological issues in a Mediterranean context.
\end{abstract}

Keywords: archaeological survey, siteless survey, artifact collection strategies, Greece, Archaic, Late Roman, Ottoman

\section{Introduction}

Siteless, artifact-level survey has been a fundamental component of regional projects in the Mediterranean for over two decades. Despite the continued vitality of site-based paradigms for documenting and analyzing material landscapes, surveys that record the artifact as the basic unit of analysis are now very common and have even become an expected standard for regional projects in the Mediterranean (see discussion and examples in Gallant 1986: 418; Bintliff et al. 2000b; Fentress 2000: 44; Francovich and Patterson 2000; Terrenato 2004: 37). Studying the landscape in terms of artifacts rather than sites is among the most important developments of the trend in Mediterranean survey toward refining and intensifying data collection (Cherry 1983: 394-97; 2002: 571-73; Terrenato 2004).

This trend has recently evoked criticism from those outside and within the field of Mediterranean survey (see Cherry 2002: 571-73). Archaeologists of the Americas (e.g. Blanton 2001) have accused their fellow researchers of 'myopia' for collecting data at such intensity that they cannot sample enough territory to address research questions framed at a regional scale; consequently, survey has become a less effective tool for approaching issues of demographic and social change, the emergence of 
complex societies, the life-cycles of civilizations, and core-periphery interaction. Even Mediterranean archaeologists themselves (Fentress 2000; Terrenato 2000a; 2004) have become skeptical of hyper-intensive survey, noting especially that the counting of pottery across the landscape can be so time-consuming that it severely restricts the geographic scope of the survey, thereby introducing more biases than it eliminates (cf. also the espousal of 'full-coverage survey' in Fish and Kowalewski 1990). In these scholars' assessment, a return to more extensive survey methods could at least clear Mediterranean archaeologists of the charges of sampling bias, particularism, and myopia, in turn repositioning archaeological survey within its proper regional setting.

These criticisms rightly point to the shortcomings of the narrow scope of Mediterranean survey, but undervalue the reasons for the development of non-site and siteless approaches (see Thomas 1975; Foley 1981a; 1981b; Dunnell and Dancey 1983; Ebert 1992) and their implementation in a Mediterranean context (see generally, Cherry 1983: 394-97; 1994: 104-105; Cherry et al. 1991: 20-22; Schofield 1991; Bintliff 2000a). While counting 'off-site' pottery in order to define 'site' scatters has been a primary motivation for artifact-level survey in the Mediterranean from its inception (Cherry 1983: 396-97; Gallant 1986), there are other more critical reasons for adopting siteless approaches. Artifact-level survey can be seen as an impulse to reveal the full range of human behavior across the landscape (Cherry et al. 1991: 20 22; Alcock et al. 1994: 137-41), or even as an explicit rejection of site-based paradigms on ontological or methodological grounds (Dunnell 1992; Bintliff 2000a; Bintliff et al. 2000b: 2). Thus, siteless methods are used not only to define sites by quantifying regional artifact patterns, but also to document the landscape in terms consistent with the reality of continuous artifact distributions (see papers in
Schofield 1991). However much intensifying approaches may decrease geographic coverage, many Mediterranean archaeologists see this as a better choice than returning to more extensive approaches, whose less intensive data collection strategies now seem inconsistent with the complexity of the artifactual record.

One primary example of this complexity, and of the difficulties involved in the analysis of intensive data sets, is the ongoing debate about the interpretation of low-density pottery distributions. Do these artifactual scatters represent meaningless background noise, nonhabitation activity areas, manured lands under cultivation, or scatters created by geomorphological processes (Wilkinson 1982; Bintliff and Snodgrass 1988; Alcock et al. 1994; Mee and Forbes 1997: 40; Bintliff 2000a: 209-11; Bintliff et al. 2002)? Or do low-density scatters of different periods represent vestigial habitations that survive poorly in the surface record due to cultural formation processes and the post-depositional effects of erosion, plowing, and taphonomic processes (see Bintliff et al. 1999; 2000a; Barker et al. 2000; Bintliff 2000a: 203-7; Schofield 2000; Pettegrew 2001; 2002; Bintliff et al. 2002)? These questions cut to the heart of current paradigms for interpreting artifact distributions, for in one reading, these scatters may be significant only in their relation to ancient habitations, while in another, these scatters are ancient habitations. Mediterranean archaeologists now seem divided on whether to accept these complexities, ever pursuing 'invisible' landscapes and missing farmsteads into the rabbit-hole of artifact patterning (e.g. Bintliff 2000a: 208-209; 2000b; Pettegrew 2001), or to abandon the chase, forgetting about the lower spectrum of artifact scatters and cutting their losses with a return to traditional site-based methods (Fentress 2000; Terrenato 2000a; 2004; Osborne 2001). While for some there may be value in truncating methodological intensiveness and artifact-level approaches to return to 
broader geographic coverage, a more promising approach for many will be to make explicit how intensive artifact-level survey contributes to fundamentally different readings of past land use. Understanding and articulating the relationship between method and knowledge production in survey archaeology will assist in designing survey methods that adequately address the research questions of individual survey projects.

This paper endorses the utility of siteless methods through the empirical evaluation of survey data, namely three case studies from the Eastern Korinthia Archaeological Survey (EKAS), carried out in the territory of the ancient city of Corinth, Greece, between
1997 and 2002 (Figure 1). EKAS intensified data collection at the expense of overall coverage (only c. $4 \mathrm{sq} \mathrm{km}$ total). We recorded the nature and context of artifact distributions more meticulously than most regional surveys in the Aegean through intensive regimes of environmental data collection and an artifact sampling strategy called the Chronotype System, although we physically collected far fewer artifacts than most surveys (see the following section). While these recording practices reduced the amount of territory that could be covered, it also allowed for a richer understanding of the temporal and spatial character of the Corinthian artifactual landscape. In the following case studies, we explore the

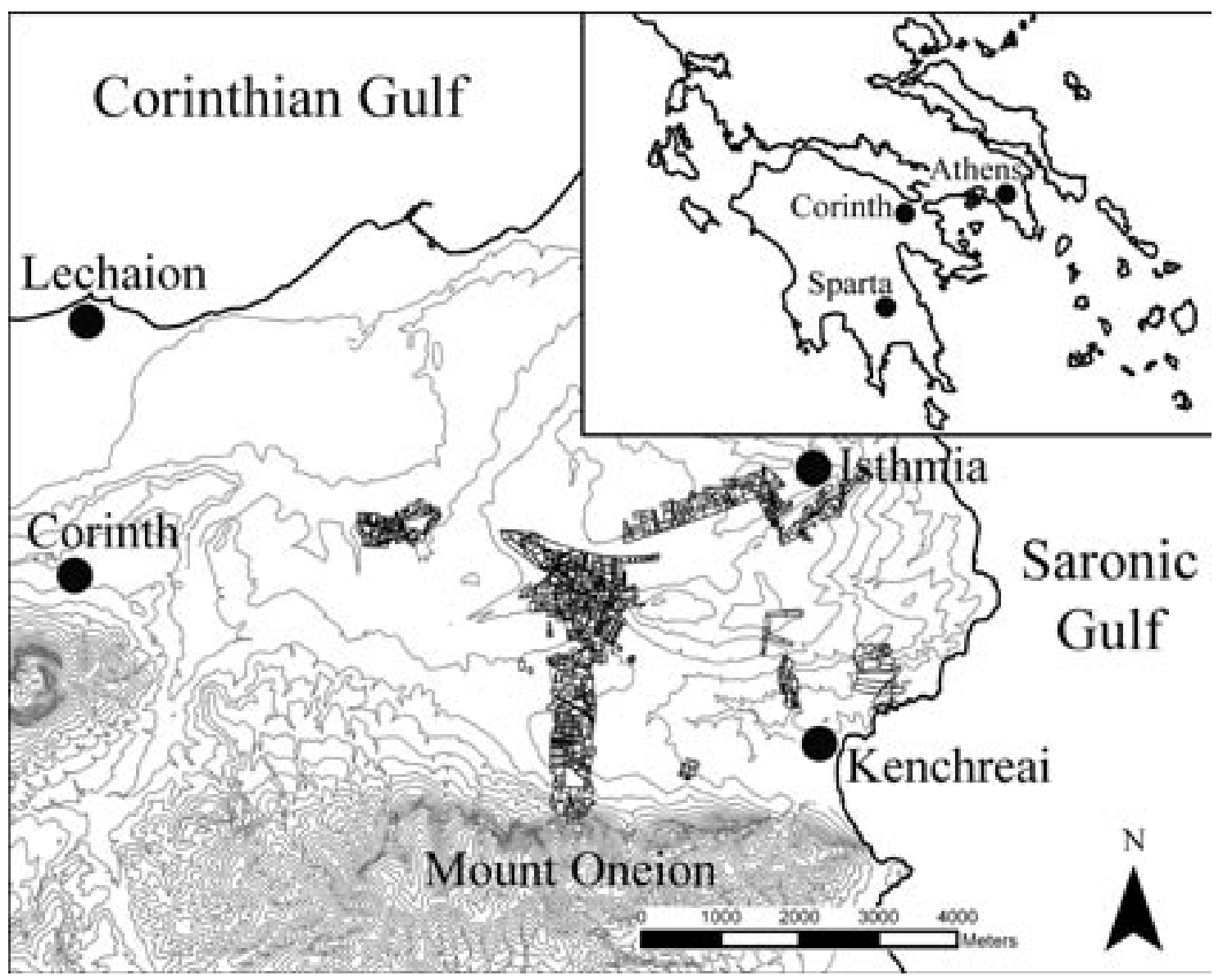

Figure 1. The eastern Corinthia, with known sites and EKAS survey units. 
implications of such intensive approaches for regional archaeological survey. Approaches based on siteless methods, we suggest, provide new insights into the nature of artifact patterning, not only in the Corinthia, but more generally in Greece and the Mediterranean, and are therefore relevant to regional surveys elsewhere. Systematically counting artifacts is not superfluous to understanding regional settlement, but is absolutely vital for reading human activity and change in artifact-rich landscapes.

\section{The Eastern Korinthia Archaeological Survey (EKAS): Scope, Overview, and Methodology}

EKAS was a diachronic, intensive, siteless survey carried out in the territory east of the ancient city of Corinth, with the goal of investigating the changing relationships of the urban center with its eastern hinterland. EKAS field teams conducted intensive survey primarily in the region between Ancient Corinth and the panhellenic sanctuary at Isthmia, but limited investigations also occurred in the coastal regions of the southern Corinthia (Figure 1). The results of the survey have appeared in numerous papers and remain the subject of ongoing research (see Rothaus et al. 2003; Tartaron et al. 2003; 2006; Caraher and Diacopoulos 2004; Pettegrew 2004, 2006; James 2005; Caraher and Gregory 2006). A fuller discussion of EKAS' methodology will soon be published in a preliminary report (Tartaron et al. 2007).

From its inception, EKAS embraced the intensive approaches common to recent survey work in the eastern Mediterranean. Building on the methodological foundations of earlier projects, such as the Pylos Regional Archaeological Project (Davis et al. 1997) and especially the Sydney Cyprus Survey Project (Given and Knapp 2003), EKAS adopted tract-level siteless survey, ${ }^{1}$ geomorphology, site-based gridded collection, geo- physical prospection, experimental survey, mortuary analysis, harbor investigation, and the use of Geographic Information Systems (Tartaron et al. 2007). We believed that the combination of these methods would foster an understanding of the archaeological record befitting its complexity and prove significant in the interpretation of artifact patterns. Moreover, the territory of the northern plain of the eastern Corinthia lies in a region rich in natural resources, in the immediate shadow of one of the most important urban centers of the Greco-Roman world. Our survey area was a major travel corridor between the eastern and western Mediterranean as well as, locally, between the city of Corinth and its panhellenic sanctuary of Isthmia and eastern harbor at Kenchreai (Figures 1 and 2). This study area bordered, or even incorporated, major sites in the Corinthia that had been subject to a long history of historical syntheses (e.g. Fowler 1932; Salmon 1984; Engels 1990; Rothaus 2000) and archaeological investigations, including extensive survey and excavation in and around Isthmia, Kenchreai, Kromna, Perdikaria and the trans-Isthmian walls (Wiseman 1963; 1978; Broneer 1973; Scranton et al. 1978; Gebhard 1993; Gregory 1993; Morgan 1999), not to mention the tradition, more than a century old, of archaeological work in the city of Corinth itself (Williams and Bookidis 2003). Given the profusion of both cultural material and archaeological and historical scholarship, an intensive approach was significant in producing new, more nuanced readings of an area that was already well known.

The employment of a wide range of data collection strategies in a region with a history of dense occupation produced one of the most intensive archaeological survey projects in mainland Greece (Cherry 2002: 573), and one of the most restricted in its geographic coverage. Field teams over the course of three summers were only able to survey intensively 


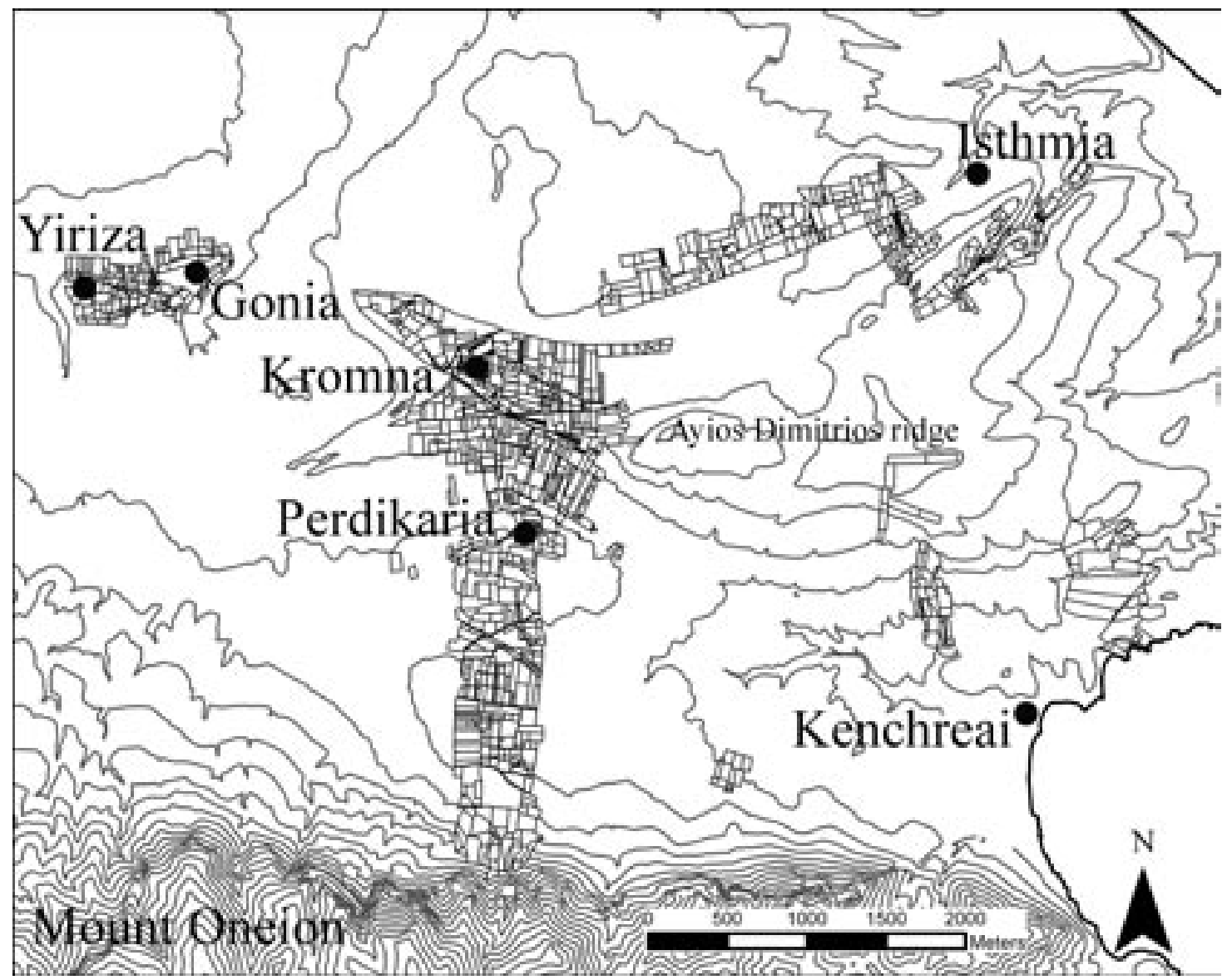

Figure 2. The Isthmian basin, with known sites and EKAS survey units.

c. $4 \mathrm{sq} \mathrm{km}$, with the result that we have a formidable record of archaeological and environmental data for a very limited area. Rather than review all facets of EKAS intensity, we will focus on that specific component of intensity most frequently targeted by critics of Mediterranean survey-the counting of artifacts distributed across the landscape-and show how counting artifacts is valuable, and perhaps even necessary, for understanding cultural activity in artifact-rich landscapes.

Artifact-level survey: Counting and Chronotypes In EKAS, as in most siteless surveys in Greece and the Aegean, field teams defined the spatial unit for collecting data so as to ensure homogeneous environmental conditions (i.e. visibility, land use, size) for the collection and documenting of artifacts in the soil matrix. Further bolstering the rigor of this procedure was the principle that archaeological units could not cross the boundaries of geomorphological units-areas formed by the same natural or cultural processes as defined by geomorphologists attached to each survey team. For each survey unit we collected artifact data and information potentially useful for later analysis, such as vegetation, visibility, and current land use, as well as methodological factors (e.g. time required to complete the unit). The survey unit, then, forms the basis in EKAS for analyzing and interpreting the distribution of artifacts across the Corinthian landscape. The minute attention to environmental factors, particularly 
geomorphology, produced units that tended to be smaller than 0.25 ha in size (median unit size was $0.21 \mathrm{ha}$ ), which reduced the amount of territory we could cover, but also increased spatial control over our data.

EKAS recorded two kinds of artifactual data in the course of survey. First, as has become common survey practice in the Aegean, field walkers spaced at $10-\mathrm{m}$ intervals walked transects across each unit, recording with tally counters the total amount of pottery, tile, lithic, and 'other' artifacts for a 2-m wide swath; under ideal conditions this provided a $20 \%$ sample density of major artifact classes for each unit. These recorded counts were subsequently used to compute the distribution of total artifact densities across the landscape. Second, to characterize the finds from each of the survey units, EKAS employed a highly intensive artifact collection strategy known as the 'Chronotype System', originally developed for and utilized in the Sydney Cyprus Survey Project (Meyer 2003; Meyer and Gregory 2003) and whose utility is currently being discussed (Gregory 2004; Tartaron et al. 2007).

A Chronotype is a unique artifact type based on specific physical attributes (material, fabric, shape, decoration, etc.), which reflect the artifact's chronological and functional character. Chronotypes employed by EKAS range from highly diagnostic fine wares, such as 'African Red Slip Form 104A', to poorly diagnostic utilitarian wares as 'Cooking Ware-Ancient'. Although most surveys have ignored poorly diagnostic body sherds, especially in an off-site context, EKAS recorded these in the hope that they might relate specific information about past land use. As we will argue below, the Chronotype System is a valuable refinement of the typical purposive artifact sampling strategy used by surveyors in the Aegean, which tends to favor 'feature sherds' (rims, bases, handles, decorated and surface-treated body sherds) and to ignore everything else as 'non-diagnostic' artifacts. Moreover, it repre- sents a more realistic and efficient solution to sampling the surface assemblage on a regional scale than so-called total collection strategies.

During survey, walkers counted with clicker-counters all pieces of pottery, tile, and lithic, and collected every unique Chronotype encountered in their swath, but no more than a single example of each individual part (rim, base, handle, neck/shoulder, body sherd) of a Chronotype. For example, a field walker who had collected a 'combed-ware' body sherd and a 'black-glazed' body sherd was not to collect additional examples of combed-ware and black-glaze body sherds in their swath, although he or she would count them as part of the total artifact count. Following survey, our ceramic analysts recorded the specific Chronotypes gathered from each unit. This information, along with the total density counts and other data collected for the survey units, was keyed into MS Access and provides the basis for all subsequent analysis.

Three points should be noted regarding our artifact sampling strategy and survey intensity. First, as discussed at length in the preliminary report (Tartaron et al. 2007), our permit from the Greek Ministry of Culture restricted us from 'collecting' (i.e. physically removing) artifacts from the field except when those artifacts were found at significant 'sites'. This restriction limited the amount of artifacts taken back to the lab and forced us to process most finds while in the field, including identification, photographing, and drawing. When compared to most other surveys in Greece, our artifact recording strategy (the Chronotype System) constituted a more intensive, higher resolution sample of the artifactual record by seeking information on the full range of artifact types seen in the field, even poorly diagnostic body sherds; but our artifact collection procedure (i.e. collection for permanent storage) was less intensive, in that we were allowed to remove very little pottery from the field. To put this into quantitative terms, our field 
teams counted with tally counters approximately 159,000 artifacts over the course of three years: a quarter of these counted artifacts ( $\mathrm{n}=38,000)$ were picked up according to the Chronotype System and recorded by the artifact processing teams, while only about 2,000 objects (1.3\% of the total counted) were collected from the field for permanent storage. We recorded very intensively in the field, but removed very few artifacts in the process.

Second, the Chronotype System is a hierarchical taxonomy that encourages broader period date-ranges when the precise period identification of pottery is in doubt. As is well known, for example, black-glazed pottery can fit into a period spectrum stretching from the Archaic to Hellenistic periods, while ridging on coarse wares is common from the Roman period (second to seventh centuries) to modern times. Chronotyping encourages broader-period groupings (e.g. Black-glazed, Archaic-Hellenistic periods or Wheel-ridged, Roman period-Early Modern) when it is unclear to which specific sub-period an artifact dates. This was especially important given our permit restrictions to process artifacts in the field without washing them in a laboratory before identification, as is typically done. There were, for instance, a small group of survey units ( $\mathrm{n}=191$ of 1,336 units) where significant dust accumulation on the unwashed pottery surface hindered precise artifact identification; in such cases, artifacts were assigned to much broader Chronotype period groupings such as, for instance, 'Archaic-Hellenistic' and simply 'Ancient'. While it was unfortunate that we could take so few objects from the field, the use of a hierarchical classification and dating schema did allow us to record all artifacts picked up by fieldwalkers, even if in less precise groupings, and had the additional advantage of constituting a 'low-impact' sample of the archaeological record (see Gregory 2004; Tartaron et al. 2007).
And, finally, our artifact recording strategy (including both total artifact counts and Chronotypes) enables the quantification of both raw counts of broad artifact classes such as pottery, tile, and lithics, as well as the kinds of artifacts found in each survey unit across the landscape. Although arguably the Chronotype System does not allow us to make exact quantitative statements about the total number of artifact types per unit-we do not know, for instance, how many pieces of Late Roman combed-ware body sherds a field walker saw and did not pick up (because redundant) — it does provide a representative sample of the artifact types that were seen in a survey unit. Hence, while the system is not designed to parse out the total count of artifacts into respective periods-as, for instance, Bintliff and Howard $(1999$; 2004) have done for survey finds in Boiotia-it is designed to measure more than simply the presence/absence of artifacts, for it provides an approximate and quantified sample of artifact types encountered in survey units. The inherent bias of the Chronotype system, in fact, is that it eliminates duplicates and thereby underestimates particularly common artifact types, including, for instance, 'Black-Glazed-Archaic-Hellenistic' body sherds and especially poorly diagnostic body sherds such as 'Medium Coarse Ware-Ancient' and 'Tile-Ancient Historic'. Consequently, we maintain that such a system of artifact recording provides an efficient and approximate assessment of the types of artifacts and periods embedded in artifact density, which is an improvement on assessing period representation according to a simple grab sample of the most 'diagnostic' artifacts (for further discussion, Tartaron et al. 2007). As the following case studies will argue, this recording technique produces a thorough record of the artifactual diversity present in each unit across the survey landscape, which allows for more subtle analyses of regional histories than do site-based approaches. 


\section{The Siteless Perspective at Archaic and Clas- sical Kromna}

Archaeologists have been slow to exploit the full range of data produced by modern intensive survey, in that despite the adoption of siteless methods in the Aegean in the 1980s, there has been a reluctance to embrace artifact-level analysis. In fact, the implementation of siteless survey in the Aegean may be seen historically as a reflex by survey archaeologists to increase the reliability and accuracy of their site identifications (e.g. Gallant 1986). Thus, rather than deconstruct the site, siteless methods in the Mediterranean have reified it (for some exceptions to this, see Bintliff and Howard 1999; Bintliff et al. 1999). This tendency is itself related to the conceptual vocabulary of the archaeological discipline in the Mediterranean and elsewhere, which is accustomed to thinking in terms of excavated sites.

Survey's role is accordingly to locate sites in time and space, which are often assumed to exist as clearly defined spatial and chronological entities (Dunnell 1992; for a critique of archaeological conceptions of space, see Smith 2003: 33-54; cf. Casey 1996; 1997). Thus, the complexities of survey data have often been simplified to mere 'dots on a map' (Cherry 1994: 97) in survey publications, despite the growing realization that there is a nearly 'continuous carpet' of artifacts for some of the regions that have been surveyed (e.g. Bintliff and Howard 1999), including - perhaps even especially-the Corinthia. A siteless perspective, therefore, has the potential to redress this problem by evaluating the data in different ways, thereby revealing more nuanced spatial patterns and regional histories that challenge our preconceptions, rather than merely reinforcing them.

A long tradition of research in our study area offers the means to compare data from previous site-based extensive surveys and EKAS's artifact-level siteless survey. In the 1960s,
James Wiseman identified a major ancient site of the Corinthia on a slight rise in a relatively flat, fertile plain at a crossroads between the city of Corinth, its eastern port Kenchreai and the panhellenic sanctuary at Isthmia (Figures 1 and 2). On the basis of an excavated inscription found in the area preserving the name 'Agathon Kromnites', Wiseman concluded that the site was an important Corinthian town known from literary sources as Kromna (Wiseman 1963: 257, fig. 4, 271-73; 1978: 66-68; Tartaron et al. 2007). We will continue to refer to this site as Kromna, although Wiseman's identification of this site with a Corinthian town called Kromna is probably mistaken (Pettegrew 2006). ${ }^{2}$ While other 20th-century extensive surveys did not recognize a settlement in this location (Fowler 1932; Sakellariou and Faraklas 1971), Wiseman observed standing walls and other architectural members (noted in 1960-61, but already absent by 1970), wells and cisterns, and surface pottery from the 5 th century $\mathrm{BC}$ to the 4th century $\mathrm{AD}$; furthermore, some excavated tombs to the west yielded Late Protogeometric and Archaic pottery (Wiseman 1978: 66, 78 n. 119). Wiseman placed the boundaries of Kromna at the locations of three cemeteries, indicated by large numbers of broken sarcophagi no longer visible today, to the east, west, and south (Wiseman 1963: 271-72). Thus, he could conclude that Kromna emerged as an important nucleated settlement-perhaps even the most important inland site on the Isthmus-at least by the 5th century BC, but could say little about its pre- or post-Classical history and extent.

During the 1999 and 2000 field seasons, EKAS produced enormous amounts of data recording the dense carpet of artifacts in this region (Figure 3). When these data were combined with Wiseman's observations, there emerged three alternatives for organizing and analyzing these data, corresponding to the methods of (1) extensive site-based 


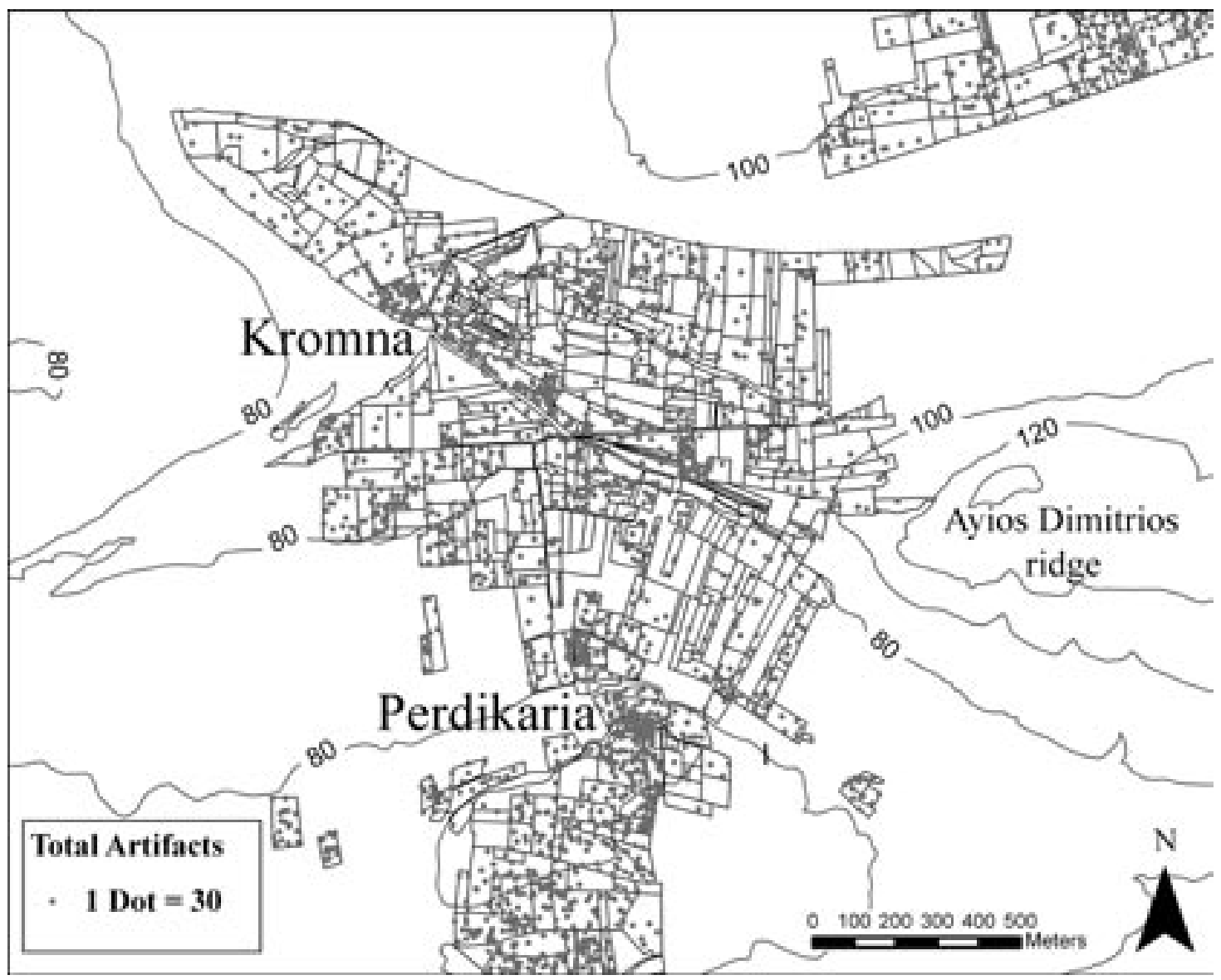

Figure 3. Artifact distribution in the Kromna-Perdikaria region.

survey, (2) intensive site-based survey and (3) intensive siteless survey. Fortunately, we are capable of discussing the results of all these methods, since Wiseman's study provides the first, and the highly detailed data collected by EKAS allows us to model the data from both intensive modes of analysis.

As discussed above, Wiseman's extensive approaches essentially identified Kromna as a site of Classical date, based on an unsystematic survey of surface finds. He defined the town as a functionally undifferentiated space bounded by the remains of ancient mortuary activity (Wiseman 1978: 66). If we analyze the EKAS data according to the intensive site-based model as implemented by most Mediterranean surveys, the artifact densities alone would suggest a more nuanced picture, with perhaps as many as 25 peaks in density in the area between, and including, the ridges of Perdikaria and Kromna (Table 1 and Figure 4). This analysis defines the densest fields as sites and deals only with the 'on-site' material, which becomes the basis for the study of the region. In this case, we have used 'artifact density per percent visible' to define sites; this statistic attempts to eliminate the bias of differential surface visibility by measuring the total artifact density of a field as compared to the density of all other fields with the same visibility (Thompson 2004: 72-78). ${ }^{3}$ In this case, we have defined 'sites' as fields that belong to the top $10 \%$ of artifact density per percent visible. ${ }^{4}$ These fields yielded an average of nearly 9,300 
artifacts per ha as surveyed by tract walking, a figure well above typical thresholds for defining sites in the Aegean. ${ }^{5}$ More importantly, however, these units possess exceptional densities within the immediate archaeological and regional context and are well above the average density figure of about 2,000 artifacts per ha for the survey area generally.

These site data (Figure 5) show a cluster of Classical sites in the area considered by Wiseman to be the core of Kromna, but add a number of sites with Archaic-Hellenistic and Classical-Hellenistic phases in the lowlying area to the south of Kromna. Together with the site on the ridge of Perdikaria (site 22 on Table 1, known to Wiseman [1963: 66, 68] as a Bronze Age and Classical site, but now known to have a Middle Neolithic and Late Roman component as well), we can confirm multiple loci of Classical activity in a larger area, specifically the area between, and including, the two ridges. These peaks in artifact density within what appears to be a larger site might be interpreted in a variety of ways: they might be seen as evidence of patchy settlement, uneven secondary deposition of artifacts, or taphonomic processes. Moreover, the Late Roman material observed by Wiseman at Kromna can now be put into a wider context, as there are a number of sites with Late Roman occupation throughout the area: more than half (13 out of 25) of the sites have a substantial Late Roman component, with another five possible sites assigned a

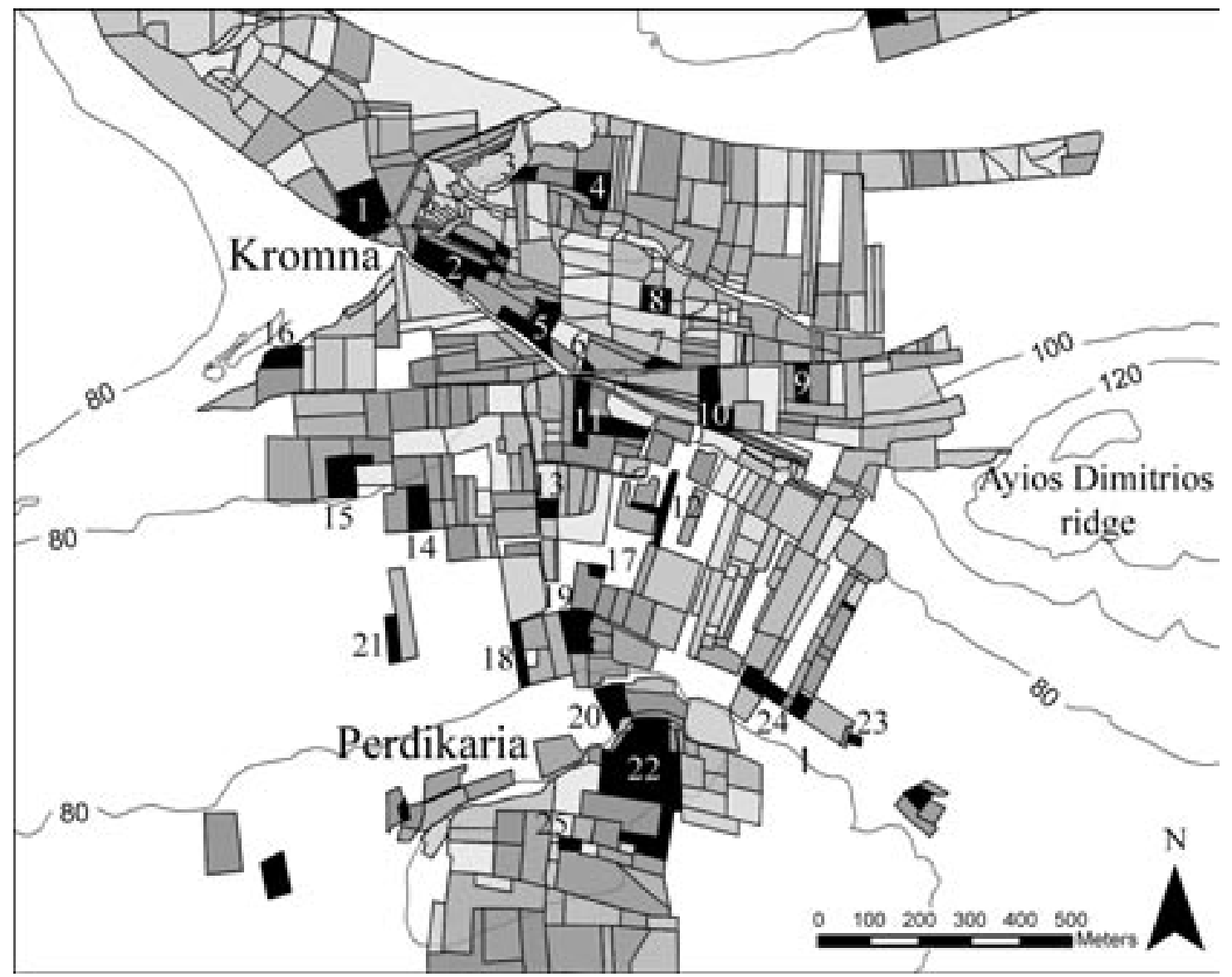

Figure 4. 'Density sites' and artifact density in the Kromna-Perdikaria region. 
Table 1. Sites defined by artifact density per percent visible in the Kromna-Perdikaria study region.

\begin{tabular}{|c|c|c|c|c|c|}
\hline Site & Area (ha) & Artifacts & $\begin{array}{c}\text { Artifacts per } \\
\text { ha walked }\end{array}$ & Primary period represented $^{1}$ & Secondary period(s) represented ${ }^{2}$ \\
\hline 1 & 0.78 & 1626 & 10,443 & Late Roman & $\begin{array}{l}\text { Archaic-Classical (Classical), } \\
\text { Roman }\end{array}$ \\
\hline 2 & 0.82 & 1249 & 7,637 & Archaic-Classical (Classical) & $\begin{array}{l}\text { Roman (Late Roman), Archaic- } \\
\text { Hellenistic }\end{array}$ \\
\hline 3 & 0.08 & 135 & 8,706 & Archaic-Classical (Classical) & \\
\hline 4 & 0.38 & 640 & 8,435 & Archaic-Classical (Classical) & $\begin{array}{l}\text { Classical-Hellenistic, Late Roman, } \\
\text { Roman }\end{array}$ \\
\hline 5 & 0.56 & 1286 & 11,583 & Classical & Archaic-Classical, Late Roman \\
\hline 6 & 0.03 & 53 & 10,029 & Late Roman & \\
\hline 7 & 0.08 & 132 & 7,918 & Roman (Late Roman) & \\
\hline 8 & 0.26 & 279 & 5,455 & Modern & Late Roman \\
\hline 9 & 0.18 & 339 & 9,516 & Classical & $\begin{array}{l}\text { Classical-Hellenistic, Archaic- } \\
\text { Hellenistic, Late Roman }\end{array}$ \\
\hline 10 & 0.55 & 1733 & 15,884 & Roman (Late Roman) & Archaic-Hellenistic \\
\hline 11 & 0.66 & 906 & 6,838 & Classical-Hellenistic & $\begin{array}{l}\text { Late Roman, Roman, Archaic- } \\
\text { Classical }\end{array}$ \\
\hline 12 & 0.24 & 262 & 5,554 & Insufficient data & \\
\hline 13 & 0.13 & 143 & 5,408 & Classical-Hellenistic & Archaic-Hellenistic (Archaic) \\
\hline 14 & 0.33 & 625 & 9,466 & Archaic-Hellenistic (Classical) & Archaic-Classical, Roman \\
\hline 15 & 0.47 & 796 & 8,456 & Roman (Late Roman) & \\
\hline 16 & 0.28 & 313 & 5,656 & Roman (Late Roman) & \\
\hline 17 & 0.06 & 163 & 13,883 & Classical-Hellenistic & Archaic-Classical, Late Roman \\
\hline 18 & 0.19 & 260 & 6,700 & Late Roman & Roman \\
\hline 19 & 0.42 & 1249 & 14,965 & Late Roman & $\begin{array}{l}\text { Roman, Classical-Hellenistic, Late } \\
\text { Medieval, Archaic-Hellenistic }\end{array}$ \\
\hline 20 & 0.35 & 398 & 5,687 & Early Helladic & \\
\hline 21 & 0.18 & 364 & 10,092 & No single dominant period & $\begin{array}{l}\text { Roman, Medieval, Geometric- } \\
\text { Archaic, Archaic-Hellenistic }\end{array}$ \\
\hline 22 & 2.42 & 5634 & 11,663 & Archaic-Hellenistic & $\begin{array}{l}\text { Early Helladic, Late Helladic, } \\
\text { Neolithic (Middle Neolithic), } \\
\text { Late Roman, Roman }\end{array}$ \\
\hline 23 & 0.04 & 42 & 5,415 & Late Roman & \\
\hline 24 & 0.39 & 538 & 7,290 & Late Roman & Archaic-Hellenistic, Roman \\
\hline 25 & 0.09 & 96 & 5,409 & Late Roman & \\
\hline
\end{tabular}

Notes

1. This field records the periods for which there are substantial numbers of sherds attested (excluding very broad chronological periods, such as 'Ancient'). If broad categories such as Archaic-Classical or Roman can be refined through the presence of more precisely dated artifacts, that is indicated by the use of parentheses.

2. These are other periods represented by significant surface material, listed in descending order. 
more general 'Roman' date that possess significant amounts of Late Roman sherds as well (Table 1). Thus, compared to extensive survey, intensive site-based survey, as is well known, reveals more periods of occupation, isolates peaks in artifact densities at larger sites (Kromna and Perdikaria) and reveals the presence of smaller sites missed by extensive surveys. A site-based analysis of the Kromna region reveals evidence of dense occupation in the Classical and Late Roman periods throughout the area, as well as concentrated activity in the Bronze Age (sites 20 and 22) and the Medieval period (sites 19 and 21) in and around Perdikaria.

However, the site paradigm, based as it is on raw counts of all artifacts representing multiple, sometimes overlapping chronological periods, fails to assess the chronological subtleties of artifact patterning in the study area. While some sites are relatively easy to interpret as single-period sites (site 9 is almost entirely composed of artifacts of certain or probable Classical date), others seem to derive their high density from the fact that they are palimpsests of lower-level activity in multiple periods, a pattern frequently noted in regional survey (e.g. Bintliff and Howard 1999). Thus, site 21, one of the highest density sites in this area (see Table 1), has no clear dominant chronological component, but contains material distributed more or less evenly among nearly every historical period. At Kromna itself, a comparison of these sites with locations of Classical artifacts

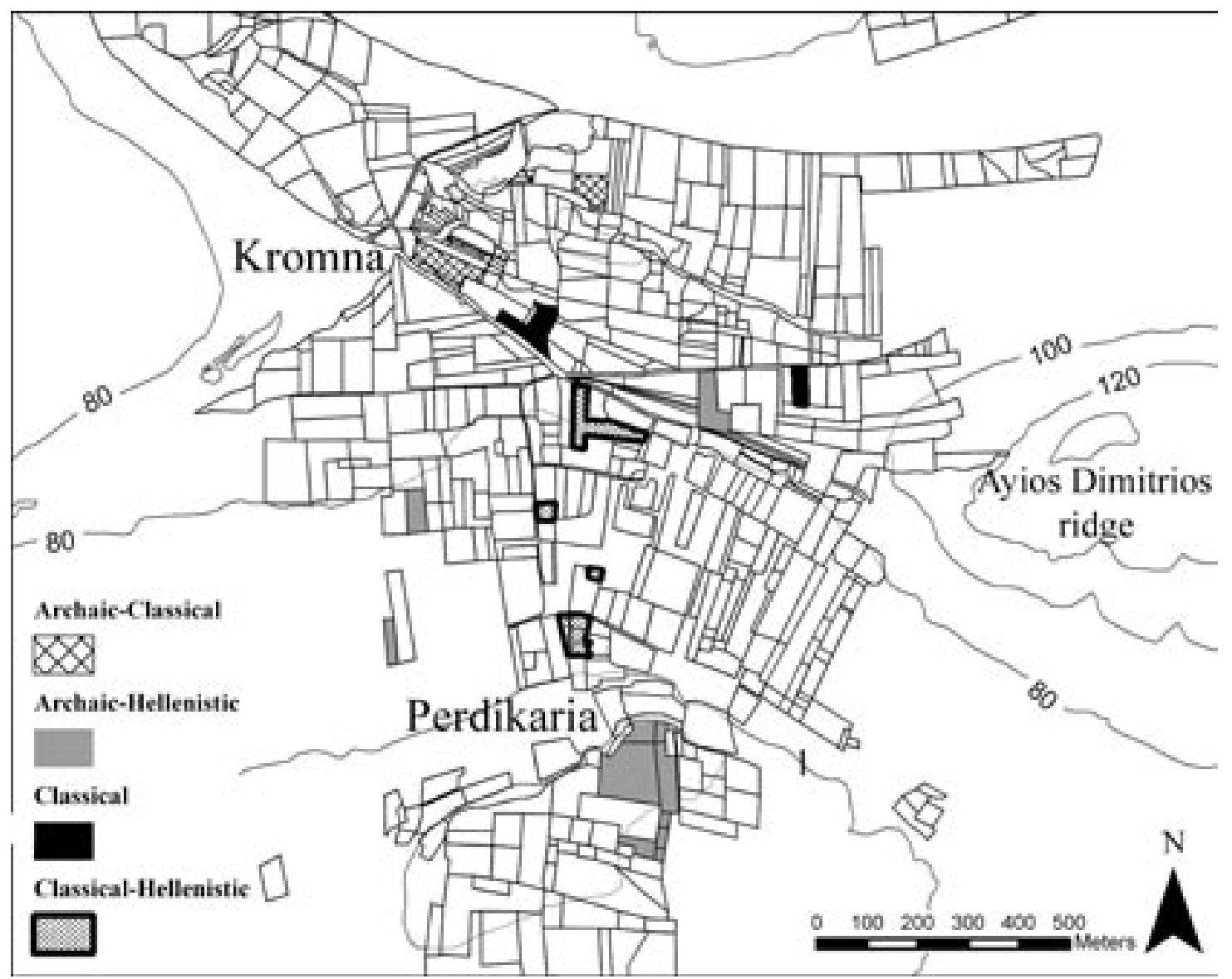

Figure 5. Greek historical 'density sites' in the Kromna-Perdikaria region. 
shows that at least two concentrated clusters of Classical pottery do not fall within sites defined by artifact density (Figure 6). The usual site-based method of archaeological survey therefore fails to represent the distribution and density of Classical pottery accurately in what is already known as an important Classical site.

More critical, however, is that the site-based method fails entirely to recognize the presence of Archaic pottery to the south of Kromna. None of our sites defined by artifact density has a strong Archaic signature, with the possible exception of site 13, and only three of the 25 sites have any Archaic sherds at all. Where Archaic sherds are present on these 'sites', they represent a tiny fraction of the assemblage: in no case do they represent more than four total sherds, or a mere $12 \%$ of sherds datable to a period shorter than a millennium. Only site 13 may be interpreted as having an Archaic phase of occupation, but its small size ( 0.13 ha) would doubtlessly lead to its interpretation as a farmstead by most Mediterranean surveys.

Within the site paradigm, then, Archaic sherds cannot be analyzed at all, because there are no clusters of Archaic finds. Nevertheless, the siteless data make it clear that there is a definite dispersed Archaic pattern in the lowlying area between Kromna and Perdikaria (Figure 7). Given the general low density of Archaic pottery in the EKAS survey area, the Archaic pottery at Kromna represents a significant concentration; nearly half (46.3\%)

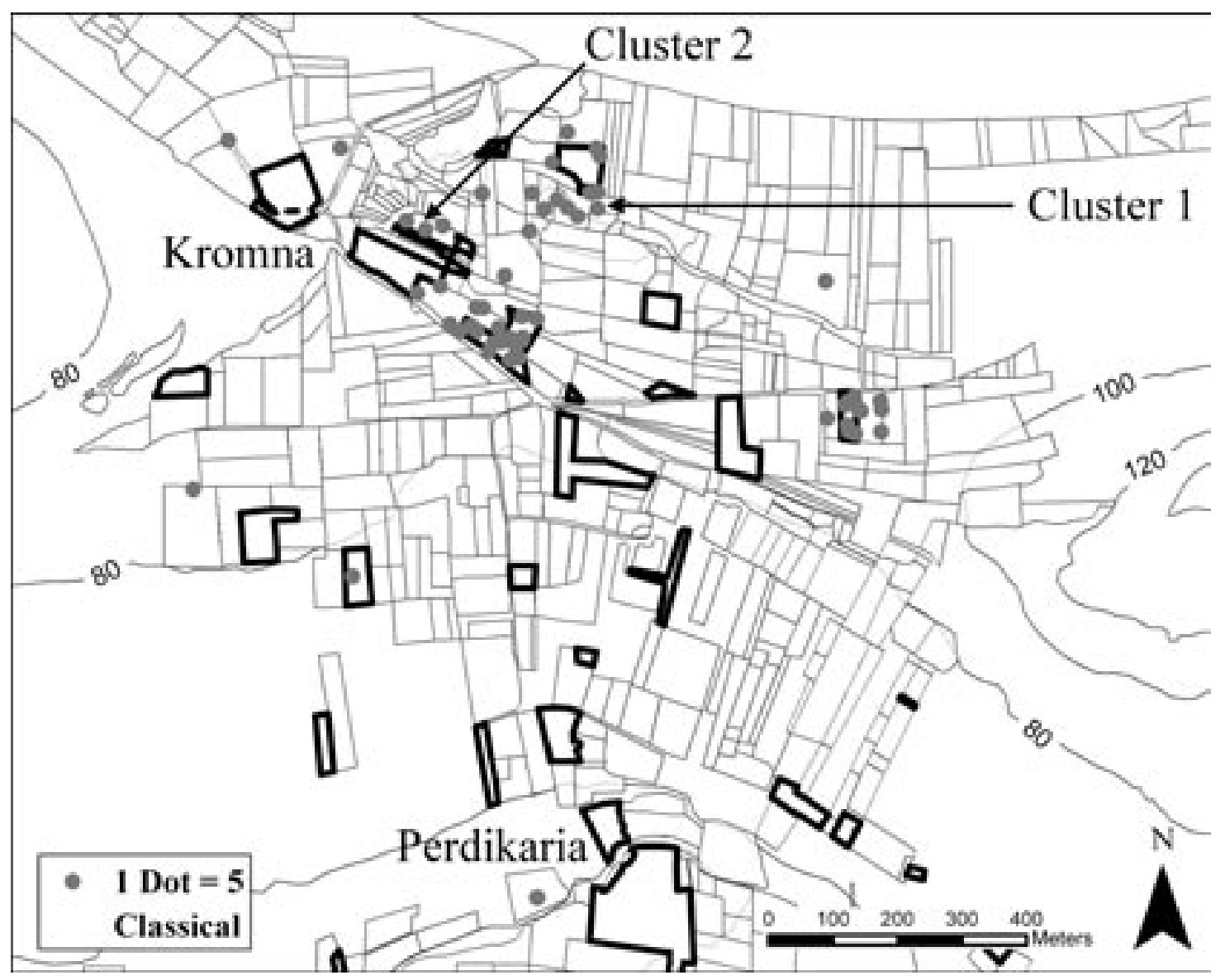

Figure 6. Distribution of Classical artifacts and 'density sites' in Kromna. 
of the Archaic pottery from EKAS was found in the Kromna-Perdikaria region, which in areal size barely constitutes 20\% of the total area surveyed by EKAS. Additionally, much material in the area dates to broader categories which embrace the Archaic period (Archaic-Classical and Archaic-Hellenistic), suggesting that much of this material may have an Archaic date as well (see below). A plausible interpretation of these data is to see the Archaic pattern as a more ephemeral ancestor to the settlement that coalesces at the crossroads immediately to the north in the Classical Period, perhaps representing a dispersed pattern of settlement such as has been proposed for the city of Corinth itself, albeit at a much larger scale, during the Geometric and Archaic periods (Roebuck 1972; Williams
1984). The presence of Archaic material is significant, since Kromna was undoubtedly one of the most important settlements in the eastern Corinthia, certainly due to the region's agricultural fertility, the extensive stone quarries located immediately to its west (Hayward 2003: 27-28), and its location at an important crossroads between Corinth and its eastern harbor (Pettegrew 2006; Tartaron et al. 2007). While site-based approaches would certainly conclude that settlement here was a new foundation, associated with the widely attested expansion in rural settlement in the Classical period, siteless data provide a more nuanced understanding of the changes in the location and the nature of its settlement.

In sum, then, it is clear that a traditional site-oriented survey in this area simplifies the

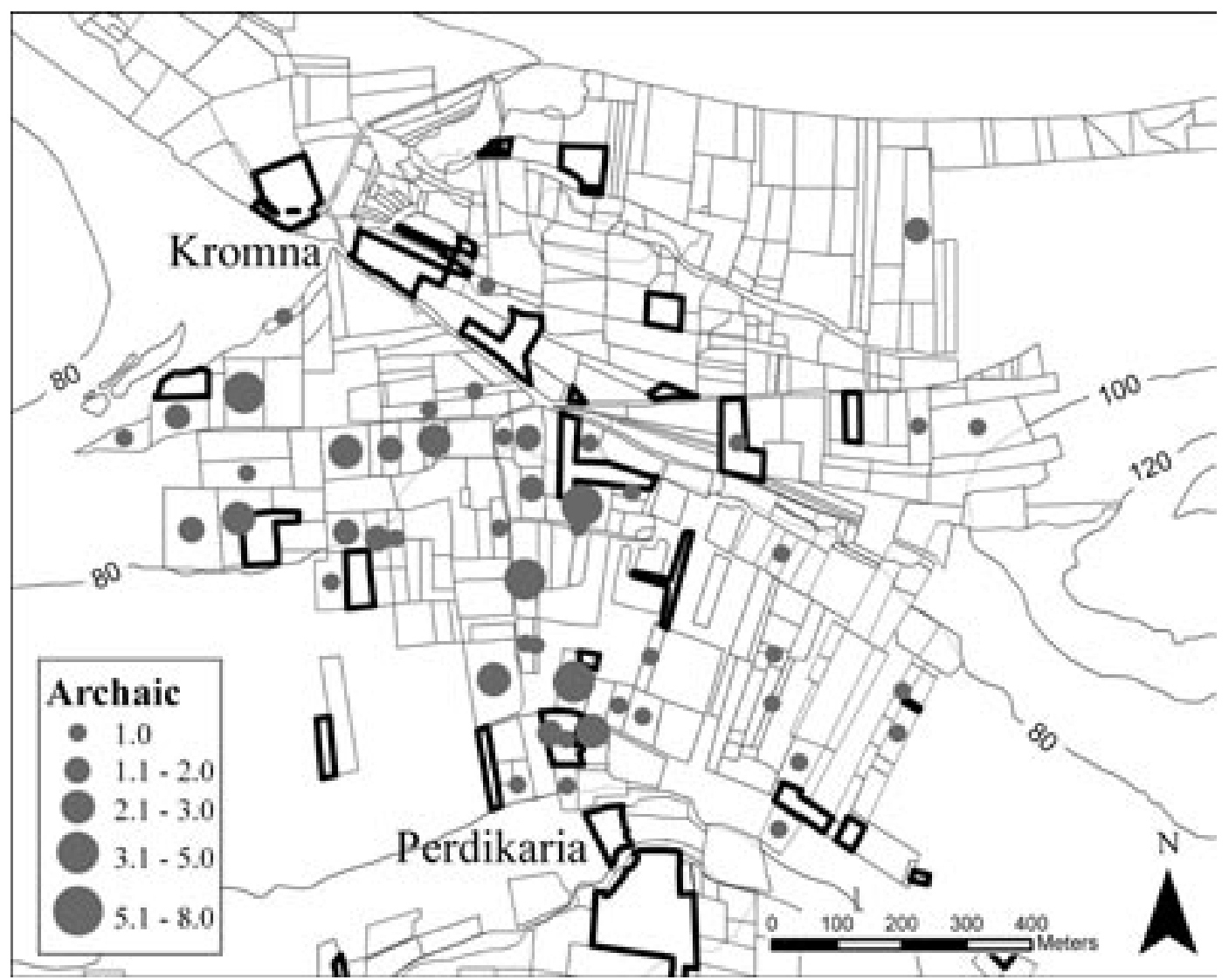

Figure 7. Distribution of Archaic pottery and 'density sites' in the Kromna-Perdikaria region. 
data by defining the densest areas as 'sites' and banishing the rest of the data to obscurity with the label 'off-site'. Besides conflating separate artifact densities by failing to differentiate between sherds dating to different periods, the site paradigm limits what the data can tell us about diachronic change. In this particular case, employing the site concept for Kromna results at worst in the complete failure to note the Archaic period, and at best in mischaracterizing its nature and extent. Of course, one or two sherds in a single field need not be particularly meaningful, nor are they easily interpreted, but a consistent pattern of relatively small numbers of artifacts does demand explanation (cf. below). Thus, siteless survey is capable of revealing low-density landscapes (the Archaic pattern) hidden by site-based methods, and representing high-density scatters (the Classical pattern) with greater precision than the site, commonly defined as an anomalous high-density scatter with clear spatial boundaries (e.g. Wright et al. 1990: 606). A careful analysis of the siteless data reveals a more nuanced history than its site-based counterparts, with nascent settlement in the low-lying farmland between Perdikaria and Kromna expanding to the north and south in the Classical period.

\section{Pattern and Problem in Late Roman Settle- ment Explosion}

Following the material abundance of the Classical period in the Greek landscape, there is a down-turn in surface finds in the Late Hellenistic and Early Roman periods, followed by a surge in surface material in the Late Roman period. This development, universally interpreted as an 'explosion' of Late Roman settlement, is one of the most consistent phenomena noted in regional survey in Greece and the eastern Mediterranean. In the prototypical pattern, a countryside sparsely inhabited between the late 3rd century $\mathrm{BC}$ and 3rd century $\mathrm{AD}$ suddenly came back to life in the late 4th and 5 th centuries $A D$ with a full variety of scattered farmsteads and country estates (for overviews, see Alcock 1993: 33-49; Bintliff 1997; Shipley 2002: 329-31; Kosso 2003; Pettegrew 2006). This settlement pattern is so consistent that historians have argued that the entire province of Roman Achaia experienced a late phase of agricultural intensification and prosperity, tied variously to population growth (Bintliff 1991: 126-27, although cf. Bintliff 1997), market economies (van Andel and Runnels 1987: 113-17), or imperial policy (Kosso 2003). The material abundance of the Late Roman countryside is further defined by the relative paucity of Early Roman and Early Medieval material, which throws the abundance of Late Roman material into sharp relief.

The historical significance of such 'settlement explosion' is that it seems to contradict traditional depictions of the rural economy in late antiquity (Kosso 2003) and the centuries-old narratives of economic, political, and even moral decline at the end of antiquity. In older accounts of the Late Roman Empire, for example, the countryside suffered from the exhaustion of soils due to cultivation of marginal territory, the widespread abandonment of land, and a general decline in agriculture (e.g. Jones 1964: 812). Recent archaeological research, on the other hand, has suggested that countrysides were flourishing in this period (see Bowden et al. 2004). Regional survey projects in Greece have shown the frequency of smalland medium-sized farms, which opposes the dramatically pessimistic view of decline in the late antique rural economy (Kosso 2003). This corpus of evidence for Late Roman Achaia has now become a standard footnote in general surveys of the expansion of rural settlement during this period (e.g. Ward-Perkins 2000: 321; Banaji 2001: 16-17, 214; Chavarría and Lewit 2004: 18-19).

Although Late Roman material is certainly ubiquitous in the Greek countryside, and 
Early Roman less so, there is good reason to think critically about why this is so and what it implies for understanding changes in land use. We may wonder especially how this pattern of explosion is exaggerated by our ability to recognize some chronological periods in the surface record better than others. Archaeologists have often commented that Late Roman pottery is much more diagnostic and easily recognized in surface survey than Early Roman pottery, and it has been suggested that this difference affects our understanding of changes in settlement (e.g. Bowden and Gill 1997a: 77; 1997b: 84). We argue that the data collected by the EKAS Chronotype System allows for a more detailed 'source criticism' of survey ceramic data that can provide us with a measure of the possible scale of distortion (for this concept applied to survey data, see Rutter 1983; Millett 1985; 1991; 2000; Alcock 1993: 49-53; Bintliff 2000b: 6-7; Sanders 2000: 172 73; Pettegrew 2004).

The methods of traditional site-based survey have certainly contributed to the notion of a Late Roman explosion, since sites are defined on the basis of large quantities of recognizable 'fossil types' such as Late Roman pottery. That is, regardless of whether surveys use absolute or relative density measures to define their sites, ultimately they assign sites to periods represented by the largest numbers of recognized artifacts. The preferred artifact collection strategies at sites, which range from unsystematic grab-sampling to total collection, provide little indication of the general frequency of artifacts across the wider landscape, and thus do not facilitate any 'source criticism' which places the artifactual 'text' in a larger context. An artifact-level siteless method as adopted by EKAS, however, can map the distribution of all artifact classes. Because artifacts were collected in a systematic and consistent manner from all units, it is relatively easy to query the constituent artifactual ingredients of Early and Late Roman patterns in both 'on-site' and 'off- site' environments. This method enables us to contextualize the presence and frequency of the very fossil types that surveys use to define sites.

Patterning Abundance: Late Roman Corinthia In surveying the rich land immediately east of the city of Corinth, we anticipated encountering abundant Roman material. Previous archaeological fieldwork in the region (e.g. Gregory 1985; Rothaus 1994; 2000; Kardulias et al. 1995) suggested that Late Roman settlement would be extensive throughout this area, and Late Roman ceramics proved to be the most frequent in the EKAS survey area. The tables below demonstrate the frequency and quantity of this material in standard tract survey. In terms of the overall amount of pottery analyzed, Late Roman material represents 1,707 artifacts-almost $5 \%$ of the overall pottery read-and was over five times more abundant than the preceding Early Roman period (Table 2). This abundance doubtless would translate into many Late Roman 'sites' in a site-based survey, as the number of recognized Late Roman artifacts would dominate other periods in high-density surface assemblages (see Table 1, with discussion, above).

A superficial interpretation of this pattern would read the relative abundance of Late Roman material as an expansion in settlement, but closer scrutiny of the ceramic data suggests that the pattern is almost entirely caused by a 'source problem' of differential diagnosticity of the pottery from the two periods. The Late Roman pattern is dramatically exaggerated by two Chronotypes, 'Spirally Grooved Ware' and 'Combed Ware' sherds, which together form $63 \%$ of the entire ceramic assemblage for the Late Roman period (Table 3). These Chronotypes represent typical closed vessel forms of Late Roman date that were characteristically surface-treated with grooving and combing prior to firing (for definition, see Robinson 1959: 6). This form of surface treatment was 
Table 2. Number of Late Roman artifacts read, compared to periods preceding and following.

\begin{tabular}{lcc}
\hline Period & Artifacts & Artifacts as a percentage of all artifacts read \\
\hline Early Roman (31 BC-250 AD) & 329 & $0.86 \%$ \\
Late Roman (AD 250-700) & 1,707 & $4.50 \%$ \\
Early Medieval (AD 700-1200) & 19 & $0.05 \%$ \\
\hline
\end{tabular}

especially common to amphora types widely exchanged across the eastern Mediterranean in late antiquity (e.g. Peacock and Williams 1986: types 43, 46, 48 and 49); consequently, their easily recognizable sherds make this period particularly visible in the field and in the EKAS data set. Early Roman amphorae, by contrast, typically have plain and untreated surfaces, and are less immediately diagnostic. While it may be possible in the field to identify plain Early Roman amphora body sherds on the basis of color and fabric, most survey projects do not even collect such pottery because they lack the obvious marks of diagnosticity.

Yet the difference that this surface treatment makes for the visibility of the periods is substantial: Late Roman is highly identifiable because these body sherds represent the largest part of the most common vessels, utilitarian coarse ware jars and amphorae. The Early Roman period, by contrast, is not immediately diagnostic in its coarse ware body sherds and is typically identified by artifacts less commonly encountered in regional survey, namely rims and handles of coarse wares, and fine ware sherds. In EKAS, the differences between periods can best be summarized by a breakdown of different functional groups loosely based on fabric (Table 4). Of the 1,707 analyzed Late Roman sherds, the overwhelming majority $(83 \%)$ are coarse wares and amphora fragments, while fine wares and kitchen wares combined represent only $15 \%$; in contrast, the Early Roman period is represented by only 329 pieces of pottery, with coarse wares and fine wares forming approximately equal percentages, and kitchen wares falling close behind.

In the eastern Corinthia, utilitarian vessel fragments were much more important 'fossil types' for the Late Roman period than fine wares, which conversely were far more important than coarse wares in signaling Early Roman presence. Thus, the Late Roman presence in the countryside may be the result of the common and easily identified coarse ware body sherds, while the identification of the Early Roman material is tied to fine ware fossil types, which are typically less common in

Table 3. The ten most abundant Late Roman Chronotypes.

\begin{tabular}{lcc}
\hline Chronotype & Number & As a percent of all Late Roman Artifacts \\
\hline Spirally Grooved Ware & 702 & $41.1 \%$ \\
Combed Ware & 371 & $21.7 \%$ \\
Amphora, Late Roman 2 & 108 & $6.3 \%$ \\
Kitchen Ware, Roman Late & 96 & $5.6 \%$ \\
Amphora, Palestinian & 82 & $4.8 \%$ \\
Phocaean Ware & 68 & $4.0 \%$ \\
Medium Coarse Ware, Roman Late & 57 & $3.3 \%$ \\
Phocaean Ware 3 & 46 & $2.7 \%$ \\
Amphora, Late Roman 1 & 23 & $1.4 \%$ \\
Total & 1575 & $92.2 \%$ \\
\hline
\end{tabular}


Table 4. Breakdown of Late Roman and Early Roman fabric groups.

\begin{tabular}{lcccc}
\hline Fabric Group & $\begin{array}{c}\text { Late Roman Pottery } \\
\text { Count }\end{array}$ & \% LR Pottery & $\begin{array}{c}\text { Early Roman Pottery } \\
\text { Count }\end{array}$ & \% ER Pottery \\
\hline Coarse Wares and & 1417 & $83.0 \%$ & 119 & $36.2 \%$ \\
Amphora & & & & \\
Fine Wares & 165 & $9.7 \%$ & 125 & $38.0 \%$ \\
Kitchen Wares & 96 & $5.6 \%$ & 82 & $24.9 \%$ \\
Lamp & 6 & $0.4 \%$ & $\ldots .9 \%$ \\
Other & 23 & $1.3 \%$ & 329 & $\ldots$ \\
\hline Total & 1707 & $100.0 \%$ & & $100.0 \%$ \\
\hline
\end{tabular}

a survey environment. Any interpretation of changes in land use and settlement between these periods would first need to take into account these factors.

The Chronotype System, in conjunction with siteless survey, allows a comparison of Early Roman and Late Roman artifact patterns in the eastern Corinthia on the basis of fossil types less subject to the biases discussed above. For instance, if we simply exclude coarse wares from our analysis, and compare fine wares, kitchen wares, and lamps, the resulting figures are roughly comparable: 165 Late Roman fine ware sherds are comparable to 125 Early Roman fine ware sherds, as are 96 Late Roman kitchen ware sherds to 82 Early Roman kitchen wares, and six Late Roman lamp fragments to three Early Roman lamp fragments (Table 4). This comparison of ceramic assemblages for the two periods indicates that the amount of certain kinds of Late Roman pottery deposited in the countryside was not substantially different than the amount of Early Roman.

Since the method of collection employed by Chronotype sampling ties the quantity of artifacts analyzed, in part, to the number of units in which they appear, it is necessary to consider the distribution of artifacts in the survey area in order to assess apparent variable diagnosticity of Early and Late Roman material. A simple comparison of the spatial distribution of Early and Late Roman ceramics demonstrates that the difference is hardly on the same scale as the raw counts of the artifacts; while Late Roman artifacts outnumber their Early Roman counterparts by more than a factor of five (5.19:1), the total area of units with Late Roman pottery is just over twice as large as the area of units with Early Roman $(2.33: 1)$, thereby reducing the magnitude of the Late Roman explosion by half (Table 5). The comparison of the two periods can be seen in Figure 8, which registers raw pottery counts.

Moreover, if we eliminate the two most common types of Late Roman pottery (see Table 3), the area covered by Late Roman pottery declines by $53 \%$ of its total area, such that the area covered by Early Roman pottery is $74 \%$ of the area of Late Roman material. A more productive comparison, however, would be between classes of artifacts, such as fine wares. This would have the benefit of comparing the distribution of certain classes of pottery that might be functionally analogous. Here we discover that the area covered by units with Early Roman fine wares is $82 \%$ the area of Late Roman fine wares. Extending this comparison to other classes, the area of units with Early Roman amphorae cover $67 \%$ of the area of units with Late Roman amphorae, and even in the murky waters of cooking pots, Early Roman vessels cover just above $50 \%$ of the area of their Late Roman counterparts. 


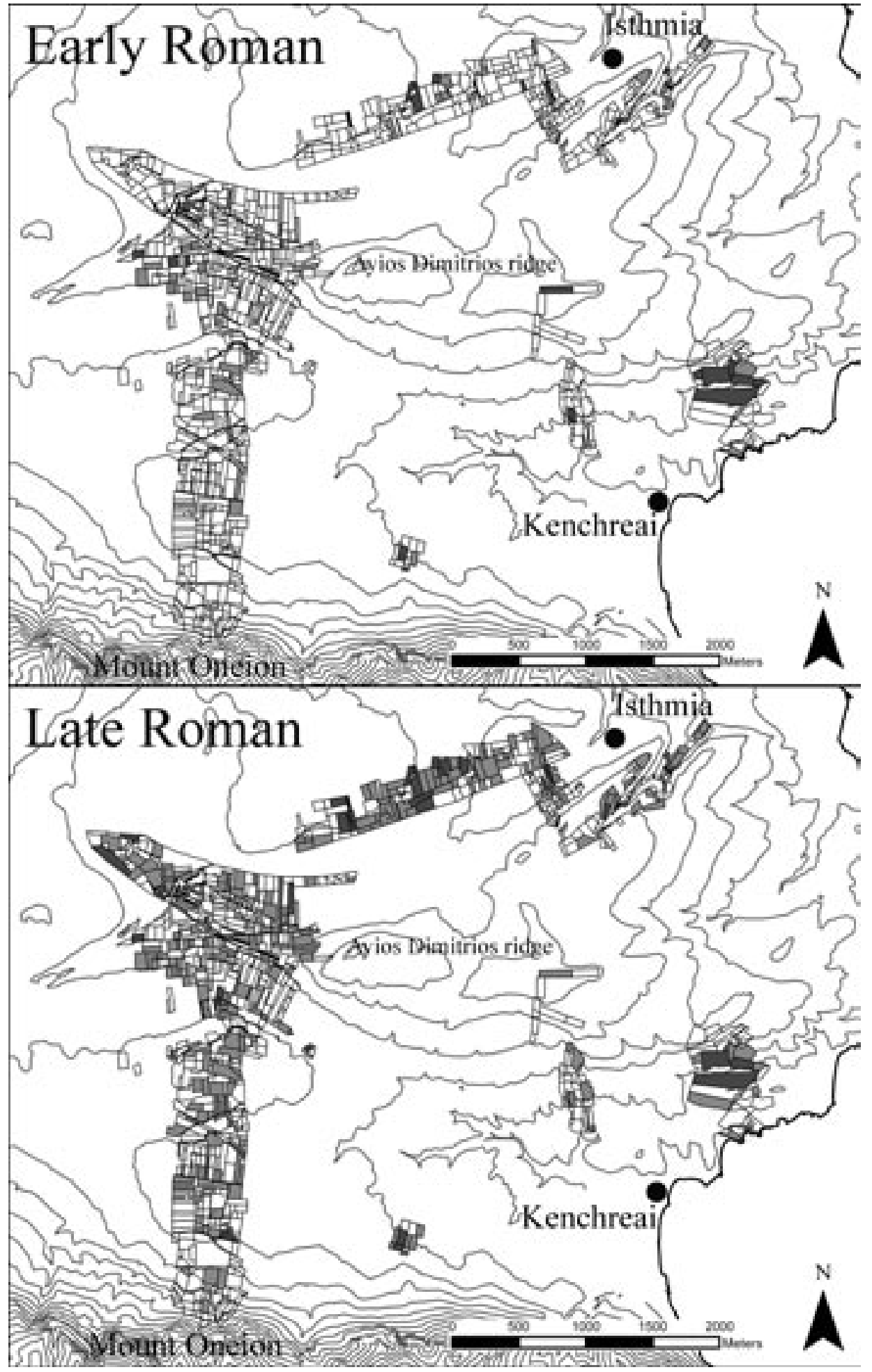

Figure 8. Densities of Early Roman and Late Roman artifacts in the Isthmian basin. 
Table 5. Units with Late Roman material, compared to periods preceding and following

\begin{tabular}{lcc}
\hline Period & Units (corresponding total area) & $\begin{array}{c}\text { Units as a percentage of all units walked } \\
\text { percentage of total area walked) }\end{array}$ \\
\hline Early Roman (31 BC-250 AD) & $193(94.3 \mathrm{ha})$ & $14.5 \%(17.1 \%)$ \\
Late Roman (AD 250-700) & $577(219.5 \mathrm{ha})$ & $43.2 \%(40.0 \%)$ \\
Early Medieval (AD 700-1200) & $14(6.5 \mathrm{ha})$ & $1.1 \%(1.2 \%)$ \\
\hline
\end{tabular}

This spatial analysis confirms the analysis above based on raw counts-namely, that the Late Roman explosion is grossly exaggerated by the more diagnostic nature of its artifacts, particularly the highly diagnostic body sherds of amphorae. Particularly striking is the parity between Early Roman and Late Roman fine wares-with respect to absolute numbers and areal coverage, Early Roman comprises about $80 \%$ of Late Roman-since these are both indicative of rural settlement and less susceptible to problems of differential diagnosticity.

A closer scrutiny of our intensively collected data, then, demonstrates that the ceramic structure of the Late Roman period has much more in common with the period that preceded it than a superficial comparison of the ceramics would indicate. The foregoing analysis demonstrates that more pottery at a later date need not be as significant as it might seem to be. We can therefore suggest that the surface record in the Corinthian plain provides a challenge to scholars wishing to argue for an 'explosion' in settlement at the end of antiquity. If this analysis has revealed certain overlooked biases inherent in the analysis of Late Roman ceramics, it should not detract from the general picture of a busy Late Roman countryside in the eastern Corinthia. In fact, highly diagnostic Late Roman pottery reveals a countryside with the 'lights turned on', a potential image of how other 'lesser historic periods' (Bintliff 2000b: 6-7), perhaps such as the preceding Early Roman, would appear if their utilitarian assemblages were as diagnostic. Thus, this analysis ultimately speaks to the constant importance of this rich and well-traversed agricultural plain throughout the Roman period to the end of antiquity.

\section{Sampling Low-density Scatters and the Ottoman Landscape}

The previous two case studies highlight the potential for interpreting low-density artifact scatters by comparing them to spatially or chronologically related higher-density scatters. In the case of Kromna, the Classical site provided an interpretive perspective on the lowerdensity Archaic material, while the highly prevalent Late Roman material allowed for a critique of the less recognizable material from the preceding Early Roman period. Our final case study seeks to analyze a low-density artifact scatter that cannot be understood based on comparisons to spatially or chronologically adjacent material. In particular, this analysis will explore the link between low overall density and low-density, single-period artifact scatters, in order to isolate shortcomings in survey sampling strategies when confronted with exceptionally small assemblages. As a means of compensating for these shortcomings, we will suggest two intuitive and probabilistic ways of extracting significance from such small, low-density assemblages. Aoristic analysis and nearest-neighbor analysis offer modest prospects for expanding our ability to understand the very kind of low-density artifact scatters that intensive artifact-level survey takes such pains to document. It should be stressed at the outset that these interpretive techniques will not permit the kind of analysis possible from more robust samples. In fact, the techniques 
presented in the following section suggest some simple and accessible methods for identifying those low-density scatters which could reward more thorough investigation by scholars more versed in material from particularly problematic periods.

One of the most important justifications for artifact-level survey and increasing intensity in data collection is that low-density scatters can shed light, on periods poorly represented in site-based collection. The Ottoman period in southern Greece has often presented archaeologists with just such a challenge. Basic ceramic types for this period and region are inadequately known (for a recent general survey, see Vroom 2003: 69-73; 2005), making the interpretation of settlement patterns heavily dependent upon the locations of modern Greek villages and documentary sources ranging from early modern travelers' accounts to Ottoman tax records (Kiel 1990; 1997; 1999; Steadman 1996; Zarinebaf et al. 2005). The traditional narrative of 17 th- to 19th-century settlement in Greece emphasizes the presence of high-density nucleated settlements populated by culturally distinct 'foreign' elites who controlled large tracts of land devoid of 'native' settlement. Thus, a repressive foreign power exploited and excluded a native population, which fled either into inaccessible mountain areas or to regions at some distance from prime lands (Finlay 1857; Bees 1936; McGrew 1985). Recent studies, however, incorporating Ottoman tax records and archaeological survey data, have suggested that this marginalized native population was, in fact, far more active and integrated in the settlement system and local economy of southern Greece (Topping 1972; Wagstaff 1978; Frangakis and Wagstaff 1987; Sutton 1994; 2000; Kiel 1999; Athanassopoulos 2004; Davies 2004; Zarinebaf et al. 2005).

A more subtle reading of the Ottomanperiod data from the eastern Corinthia can add nuance to the traditional assessment that nucleated settlements and centralized, largescale exploitation of the countryside typified this period (for a general overview of this period in the EKAS area, see Gregory 2006). Although the absence of substantial amounts of Ottoman-period material in eastern Corinthia confirmed that any large economic or administrative center must have stood outside our survey area, this is not evidence for the absence of Ottoman-period activity altogether. Scholars have generally struggled to recognize Ottoman material in the landscape from a very limited number of fossil types, although this is now changing. In general, they have depended on the distinctive greenglazed fine ware as the primary signature of its presence or absence (Davis 1991: 133; Vroom 2003: 69-73). For EKAS, these weaknesses in identifying pottery may have contributed to the paucity of Ottoman-period artifacts recognized in the survey area. The challenge presented by a data set shaped under these conditions is to devise ways to identify areas that will reward future (and undoubtedly more intensive) investigation, and to avoid the conclusion that the absence of evidence provides evidence for absence. This case study will examine such Ottoman material deriving from units with low overall artifact density as a means of exploring potential narratives of Ottoman land use in the eastern Corinthia, as well as considering wider issues relating to sampling in a siteless survey environment.

During the 1999 season, EKAS documented four units with Ottoman-period (AD 15371829) material and three units with material potentially datable to that period from a group of 23 units extending over approximately 6 ha on the north slopes of Mount Oneion (Figure 9). The aggregate density of these units, approximately 1,500 artifacts per ha, is well below the mean artifact density (c. 2,000 artifacts per ha) for the survey area in general, and far below the sustained high-density 'onsite' scatters typical of nucleated habitation 
areas such as Kromna (9,300 artifacts per ha; see above). Only five of the units $(32,34$, 38,40 , and 72) produced densities in the top $40 \%$ rank of EKAS survey units, and most of the units in this area fell below mean artifact density for the survey as a whole. The survey's emphasis on intensive data collection provides a valuable context for understanding the distribution of datable material within the context of low-density units. In particular, the contextual data collected by EKAS allows us to identify potential reasons for the low artifact density in this area and consider the implications of low-density units on the sampling of material from the surface assemblage.

Low-density units, particularly those that produce only a small number of artifacts, severely limit the opportunities for profitable analysis. In many cases the small number of artifacts collected from a given area is the product of sampling strategies designed to locate and document more robust concentrations of cultural material and a desire for a relatively high degree of spatial control. Siteless surveys in the Mediterranean typically employ field procedures that sample the landscape according to spatial area (e.g. geomorphological units or modern field boundaries) rather than, for instance, number, date, or character of artifacts (e.g. a site-based survey might 'chase densities' to produce a robust sample by collecting at a higher intensity until perceived breaks in density). The former approach is satisfactory for documenting and comparing the raw or aggregate density of artifacts across a given area (see above, for the limited analytical value of this

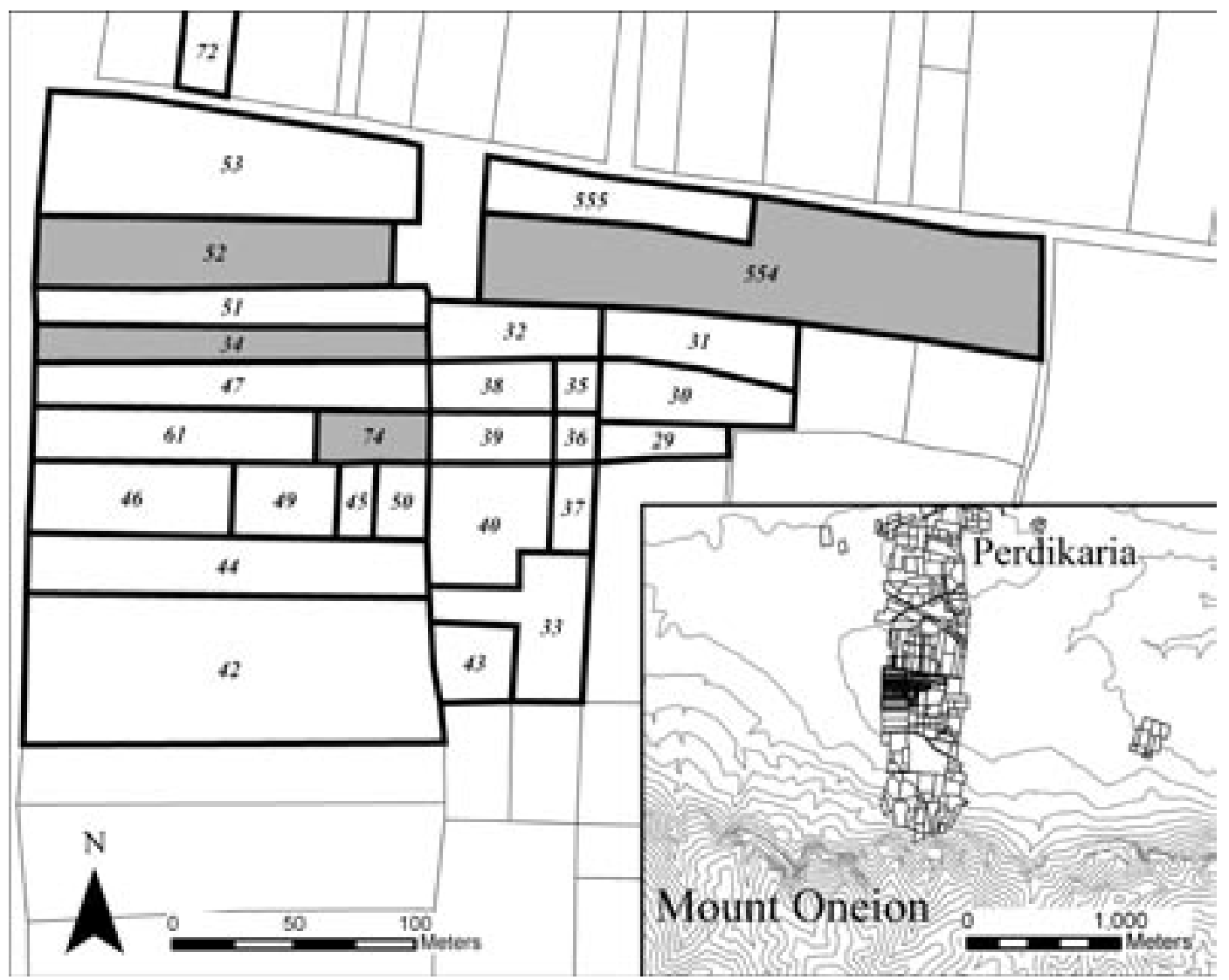

Figure 9. Units with Ottoman material on the northern slopes of Mount Oneion. 
approach), but can fall short when attempting to assess and compare the chronology and function of surface assemblages of varying density across larger regions. In high-density units surveyed by EKAS, for example, our use of the Chronotype sampling strategy detected a large number of different periods present, trending toward redundant chronological data with more than one artifact type per period. Low-density units, on the other hand, tended to produce more chronologically homogeneous assemblages (Figure 10). Not only were fewer periods represented in a smaller assemblage, but in low-density units we were also less able to date artifacts to specific periods (for discussion of this point, see Bintliff and Snodgrass 1985). Hence, low- to average-density assemblages are more apparently homogeneous because of fewer possible periods represented, as well as the predominance of pottery that can only be assigned to broad chronological periods. This latter trend, while unanticipated, correlates with the overall preponderance of weakly diagnostic pottery in all assemblages, which becomes more prevalent as the sample size and number of periods present in the overall assemblage decreases. A sampling strategy designed to manage and contextualize archaeological material observed on the surface assumes that chronological variation within a population of pottery is closely tied to artifact density.

The potential causes of low artifact density in any unit of space are well discussed in Mediterranean survey literature; possibilities include the nature of settlement and discard behavior, geomorphology, and taphonomic and other post-depositional processes such as plowing (Bintliff and Snodgrass 1988; Alcock et al. 1994; Snodgrass 1994; Fentress 2000; Van de Velde 2001). Beyond behavioral and geomorphological factors, lower artifact density (or the total absence of surface finds)

\section{Tract density and the average number of chronotypes and chronological periods represented}

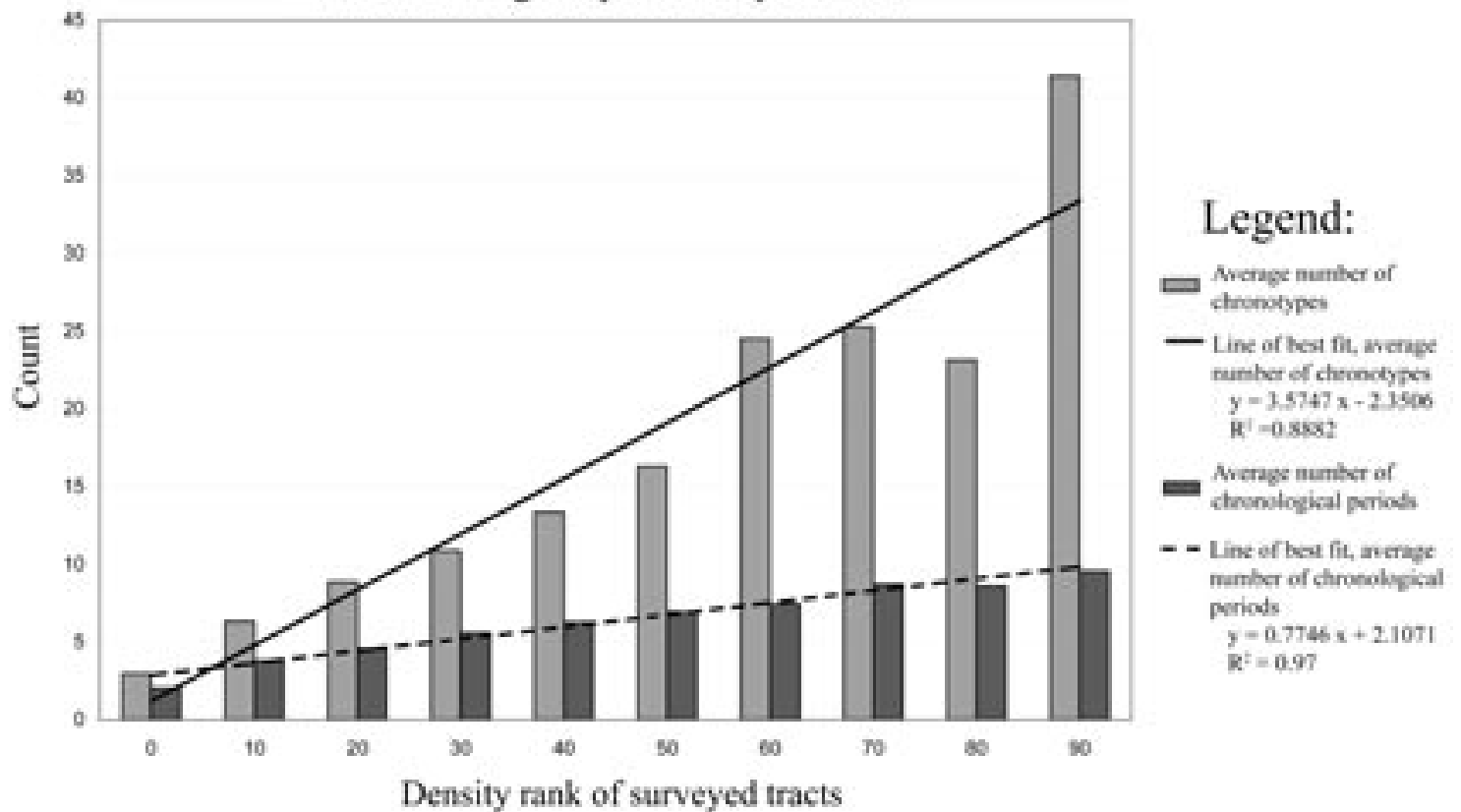

Figure 10. Comparison of the average number of chronological periods and average number of chronotypes represented on the basis of density rank of surveyed tracts. 
is frequently attributed to limited surface visibility (e.g. Ammerman 1985; Terrenato $2000 \mathrm{~b}$ ), which is principally defined by the amount of the surface free from vegetation or other obstructions. In fact, variations in surface visibility across a survey area are sufficiently common in Mediterranean survey that archaeologists often present overall artifact densities 'corrected' for surface visibility. The techniques designed to normalize density figures, however, often do little more than mask the degree to which surface visibility affects our sample of a putative total assemblage of artifacts present on the unobstructed surface. ${ }^{6}$

A useful display of the significance of visibility on the character of the sample from a unit is shown in Figure 11. This graph displays the effect of visibility on the average precision with which we can date a collected artifact: our chronological precision increases as our visibility increases. This trend reflects the greater chronological diversity present in a larger sample and influences our ability to describe discrete chronological 'events' in archaeological space. It is valuable to note that surface visibility has an even more linear and significant relationship to the precision represented in the collected surface assemblage than does overall artifact density. This is particularly striking because the number of periods and Chronotypes represented has a more linear and significant relationship to artifact density than to overall visibility. Visibility, then, more so than total density, biases our interpretation of the surface assemblage toward the predominant component in all assemblages: those relatively undiagnostic (both in terms of chronology and function) artifacts which can only be associated with broad periods (Figure 12). Perhaps certain artifact types, such as poorly diagnostic roof-tiles or thick coarse wares tend to survive geomorphic and anthropogenic (e.g. plowing)

\section{Average chronological precision of recovered artifacts by visibility}

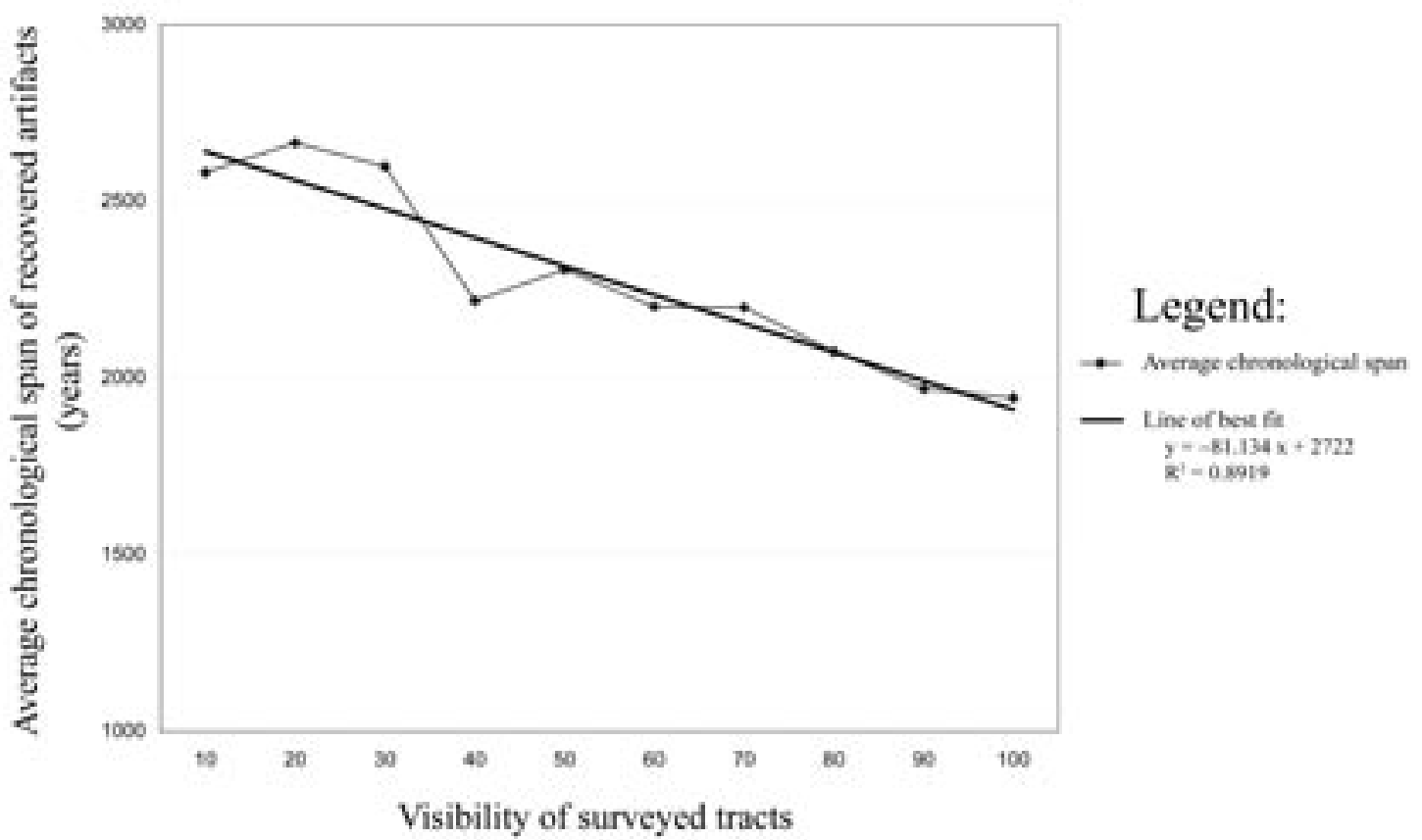

Figure 11. The relationship between surface visibility and the average chronological span of artifacts in surface assemblages. 
processes more readily and remain more obtrusive than fine-walled and highly diagnostic fine wares which form the core fossil-types of most ceramic assemblages (for some experimental data which suggest this explanation, see Schon 2002: 163-79).

The limitations imposed by visibility on our ability to produce a robust sample of the assemblage are particularly significant for the interpretation of our group of 23 units considered in this case study. Two of the four units (52 and 554) which produced definite Ottoman material had visibilities of $30 \%$ and $40 \%$. This drops our sample of the surface from $20 \%$ in an ideal environment to less than $10 \%$. Moreover, a number of the other units in our subset of EKAS data exhibit rather inferior surface visibility, although the overall visibility in this area was $56 \%$, only slightly lower than the figure $(58 \%)$ recorded for the survey area as a whole.
To summarize our assessment of the EKAS data so far, it would seem that units with average to low visibility are unlikely a priori to produce the same quantity and quality of chronological data as units with high visibility in a way that suggests some independence from trends associated with low overall artifact density alone (see, e.g., Van de Velde 2001: 36-38). This leaves archaeologists who are engaged in siteless survey with the problem of extracting comparable information from assemblages and samples that may, in fact, be fundamentally incomparable. The use of the Chronotype System, which required that each lot of artifacts have an associated chronological range, no matter how broad, provides us with one method to analyze ceramic data. A particular approach that is well suited to data collected through the Chronotype method is 'aoristic analysis' (for this concept, see Johnson 2004), which, together with nearest-

\section{Visibility and the proportion of artifacts datable to 1000 years}

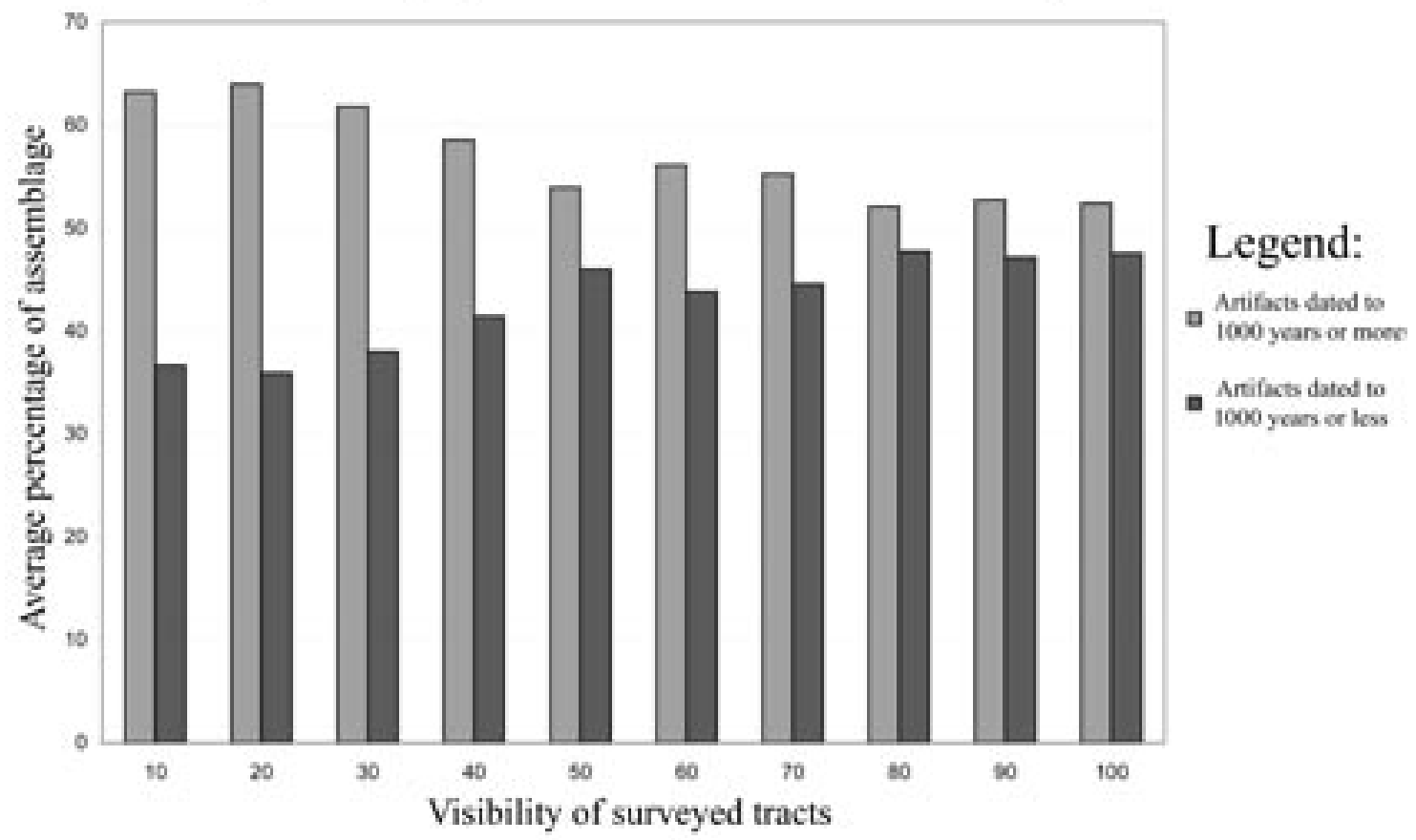

Figure 12. The relationship between surface visibility and the average percentage of the assemblage datable to more or less than 1000 years. 
neighbor analysis, can aid in the interpreting of periods poorly represented in the archaeological record, whether due to issues of sample size, the variability of expertise among the archaeologists involved, or the varying degree of diagnosticity of certain ceramic types.

Aoristic Analysis and Nearest Neighbor Analysis Aoristic analysis is a method for defining the probability that specific 'events' or sub-sets of time occurred at particular points within more general chronological arrays. For example, we can argue that pottery made in a distinctive Ottoman style dates to sometime within the broader period of Ottoman influence in the Corinthia (AD 1537-1829). We can also suggest, however, that material dated broadly to the 'Medieval' period (for EKAS, dated AD 700-1829) could have also been produced during the Ottoman period, although with less certainty. We can even argue that pottery datable only to the 'Medieval-Modern' period (AD 700-2000) could have a possible Ottoman date. This being said, it is nevertheless the case that the probability of a sherd with a broad period like 'Medieval-Modern' or 'Medieval' dating to the more specific Ottoman period is less than the probability of a sherd with a more narrow date. Aoristic analysis provides a means of comparing artifacts that are datable with varying degrees of specificity, by considering the probability that any group of artifacts could date to a specific sub-unit (e.g. a year or decade) of a time span under consideration (Fentress and Perkins 1988; Fentress et al. 2004). While this approach is clearly artificial, it is nevertheless a useful way of analyzing data collected and characterized in chronological typologies that are often quite independent from the realities of human behavior.

For the 23 units examined here, four units have definite Ottoman material, and four units have material potentially datable to the Ottoman period. If we assume each artifact has an equal chance of appearing in every year during its potential time span, then the material datable to the Medieval-Modern period in units 34,46 , and 42 has an approximately $30 \%$ chance of dating to the Ottoman period; unit 72 has one piece of Medieval pottery with a 36\% chance of an Ottoman date; units 34, 52,554 and 74 all have material securely datable to the Ottoman period. One could argue, of course, that a $30 \%-40 \%$ chance that an artifact actually dates to a given time period is rather too imprecise for any compelling argument. But if we assume that those factors contributing to the formation of our surface assemblage, such as density and visibility, have no direct relationship to the nature of artifacts collected (i.e. our ability to date them, their function, etc.), then this is better than simply discarding data on methodological grounds as being too imprecise for even tentative conclusions. Moreover, the well-known variability of artifact 'supply' during certain periods does not necessarily invalidate this interpretive tool, but rather reinforces the fundamental difficulty of using typologies to model any behavior. That is, an archaeologist collecting data using a particular method must be willing to accommodate the interpretive paradigms available for assessing these same data.

We can introduce an additional analytical tool that will help us refine our understanding of probabilistic data-namely, the spatial proximity of these units to one another. While there are many ways to assess spatial relationships between units, one commonly employed in survey archaeology is nearest-neighbor analysis (Lock et al. 1999: 60). In this case, we can interpolate our irregular unit data to a regular grid of $1 \times 1 \mathrm{~m}$ squares, each with a value representing the probability that the survey unit has an artifact that falls within the Ottoman period. These squares can then be used to establish a new grid made of $1 \times 1 \mathrm{~m}$ squares, each with the value of the mean of all $1 \times 1 \mathrm{~m}$ squares within a circle $20 \mathrm{~m}$ in diameter. Thus, 
we create a smoothed grid with the value of the grid squares being the mean probability of their nearest neighbors. Figure 13 shows how our subset of 23 units forms a concentration of possible Ottoman period material anchored by several areas where definite Ottoman material is documented.

It is, of course, impossible to propose on the basis of 5-7 Ottoman-period artifacts, even bolstered by aoristic and spatial analysis, a definite Ottoman-period settlement on the lower slopes of Mt. Oneion in the Corinthia. It would seem likely that this area situated at the fringes of cultivatable land would be well situated for seasonal habitation, activities related to agricultural production, or other small-scale settlement (see Gregory 2006).
This kind of analysis, however, does highlight some shortcomings and prospects for intensive, siteless survey. One could, for example, use analytical tools such as these to formulate strategies to compensate for the sampling bias common in low-visibility and low-density units. Units such as these could receive modified collection strategies with compressed walker spacing or even, as so often in the case of sites, gridded collections. In fact, employing a total collection ('hoovering' or 'vacuuming' all artifacts) circle over a mere $5 \%$ of the surface area of several units of varying density in a recent survey on Cyprus produced assemblages which averaged a sobering 100\% more pottery than was counted over the course of a standard 20\% fieldwalked sample of the same

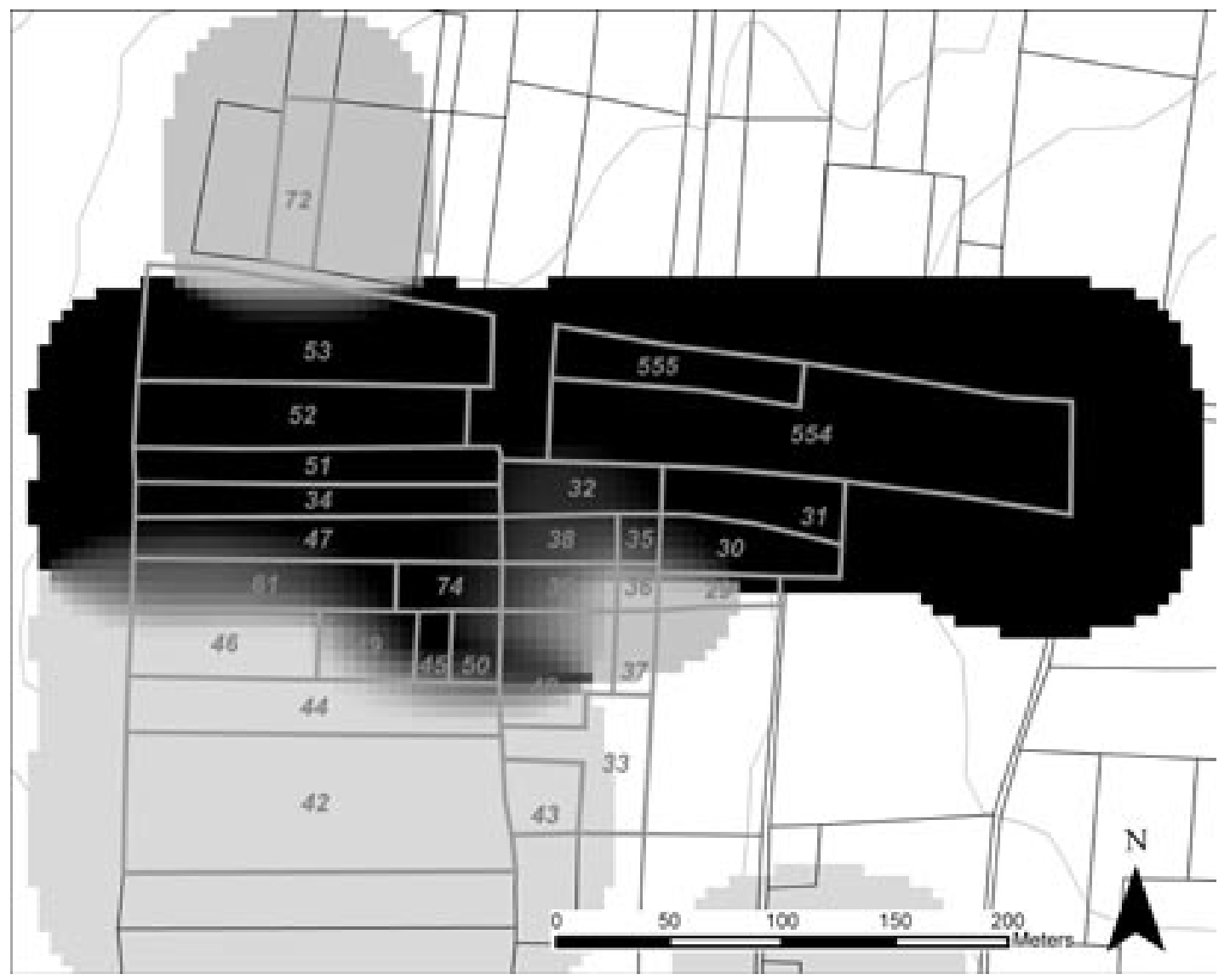

Figure 13. A nearest-neighbor analysis showing the average probability of the presence of Ottoman material, with higher probabilities shown in black. 
space (Caraher et al. 2005; see also Van de Velde 2001). Such methods run counter to the prevailing tendency among survey archaeologists to lavish additional attention on highdensity units-precisely the units most likely to produce redundant chronological or functional data-and ignore those units where our sampling strategy could benefit most from additional rigor. This is all the more salient considering the typical focus of survey archaeology in the Mediterranean on the hinterland of regional centers, where the small farm, the country house, and seasonal settlements predominate.

\section{Conclusions}

In this paper we have argued that the trend in Mediterranean survey archaeology toward intensification relates directly to issues of 'large-scale social and demographic processes' which survey was originally designed to address (Fentress 2000; Blanton 2001: 629). One can hardly find a larger or more significant process addressed by Mediterranean survey than the 'Late Roman explosion', which our siteless and intensive data set confronts directly and forcefully. In fact, the Late Roman explosion is exactly the kind of process-being essentially demographic and economic in nature-that survey is designed to analyze. Moreover, even in the densely populated material landscapes that characterize much of the Mediterranean, site-based archaeological survey often barely records important historical periods, or else significantly distorts their extent and spatial configuration. Since long-term cycles of expansion and contraction are, in general terms, the types of issues survey is used to discuss, the analysis of why and how certain periods appear under- or over-represented in our data cannot be peripheral to larger debates, but must remain central to the empirical verification that the patterns observed in our data are valid.

(C) The Fund for Mediterranean Archaeology/Equinox Publishing Ltd., 2006
Moreover, siteless survey detects spatial patterns in the data that site-based methods simplify and flatten out. Site-based methods are designed to record patterns in overall artifact density, define analytical units or 'sites' and collect data about them, whereas siteless survey coupled with intensive data collection also enables the analysis of the spatial patterning of all classes of artifacts: tiles, Archaic pottery, agricultural processing equipment, even entire assemblages. Crucially, spatial patterns formed by overall densities and different artifact types are, in our experience, rarely congruent. Thus, in many cases, the complex nature of the surface record requires detailed data collection in order to characterize adequately the spatial patterning of even common artifact classes such as Classical pottery. This is the case even more so for rarer artifact types, whose presence tends to be suppressed in site-based methods.

An intensive siteless data set, then, can provide significant insight into the factors responsible for relatively different visibility thresholds of successive periods in Mediterranean countrysides both by revealing 'hidden landscapes' and by noting the relative overand under-representation of certain classes of surface materials. While undoubtedly surveys will produce different artifact patterns corresponding to the particularities of regional histories, methodology, and systems of artifact analysis, artifact-level analysis and some degree of source criticism remain vital to understanding and interpreting chronological patterns of human activity from surface remains. Counting pottery according to rational and consistent principles like the Chronotype System is not simply a methodological exercise that bogs down survey, but a necessary component for interpreting the whole.

The critiques of siteless survey to which our work responds note quite correctly that Mediterranean survey tends to take for granted that its increasingly intensive methods produce better, more accurate data. While siteless 
methods and analyses do require justification, they do so no more or less than the traditional site-based approaches to which some now advocate a return. What is clearly needed is not outright privileging of one paradigm over another, but explicit discussion of how different survey methodologies produce varying data sets and readings of cultural landscapes. In this paper, we have attempted to show how one principal component of intensive survey in the Mediterranean-counting and recording the distribution of artifacts-is absolutely vital to answering questions of regional development and social change. While artifactlevel survey is not the only good way to 'do survey' and archaeological projects should devise methods and analytical approaches appropriate to their research questions and paradigms (Redman 1987), counting artifacts distributed across the landscape remains fundamental to the field of survey archaeology generally and must especially form an active component for surveys carried out in artifactrich environments.

\section{Acknowledgments}

We would like to thank the directors of EKAS, Timothy Gregory and Daniel Pullen, for encouraging us to analyze and publish this material. We have benefited from their comments, as well as those of John Cherry, William Dancey, Michael Given, Guy Sanders, Robert Schon, and Thomas Tartaron. We also appreciate the valuable feedback given by the JMA reviewers. An earlier version of this paper was given in April 2005 at the 70th Annual Meeting of the Society for American Archaeology in Salt Lake City, Utah.

\section{About the Authors}

William R. Caraher is Assistant Professor of History at the University of North Dakota. He received his $\mathrm{PhD}$ from The Ohio State Uni- versity in 2003. Since 2003 he has been the co-director of the Pyla-Koutsopetria Archaeological Project on Cyprus. His research interests include landscape archaeology, ritual, space, and social structure in Early Christian Greece.

Dimitri Nakassis is Visiting Assistant Professor of Classics at Trinity University. He received his $\mathrm{PhD}$ from The University of Texas at Austin in 2006. His dissertation examines the role of individual agents in the reproduction of the Mycenaean state through a prosopographical analysis of named individuals in the Linear $B$ tablets from Pylos. His interests include the Aegean Bronze Age and its literate administration, landscape archaeology, Archaic epic, Greek religion, and social theory. He is currently associated with two archaeological projects: the excavation of Mycenaean chamber tombs at Ayia Sotira in the Nemea Valley and the Pyla-Koutsopetria Archaeological Project.

David K. Pettegrew is Assistant Professor of History at Messiah College. He completed his $\mathrm{PhD}$ in Ancient History at The Ohio State University in 2006. His dissertation is a landscape study of Corinth's famous eastern territory, the isthmus, between the 3rd and 7 th centuries AD. His research interests center on using landscape approaches to writing local and regional history in the Roman and Late Roman periods. He has been involved in excavation and survey projects in North America, Greece, and Cyprus, and is the field director for the Pyla-Koutsopetria Archaeological Project.

\section{Notes}

1. 'Tracts' are the basic spatial units of investigation, typically consisting of agricultural fields less than one hectare in size, in which there is uniformity with respect to factors affecting archaeological investigation: visibility, land use, vegetation (e.g. Wright et al. 1990: 604). 
2. There are good reasons to doubt the identification of this settlement with the Kromna known from literary sources. There are two poleis known by this name: Kromna in Paphlagonia (Homer, Il. 2.855), and a city in Arcadia known as Kromnos, Kromoi, and Kromna (Xenophon, Hell. 7.4.20-28; Callisthenes apud Athenaeus 10.75.19, 10.75.33; Pausanias 8.3.4, 8.27.4, 8.34.5); there is no evidence for a Corinthian polis or town by this name. The only literary evidence for a Kromna in the Corinthia is a fragment of Callimachus (fr. 384 [Pfeiffer 1949: 311-18]). However, in Callimachus it refers to a place on Poseidon's sacred isthmus, and is contrasted spatially with Lechaion, Corinth's northern port on the Corinthian gulf. In Callimachus, Kromna and Lechaion define the Isthmus, and Kromna therefore probably refers to Kenchreai, the eastern and Saronic port of Corinth (Pfeiffer 1949: 313). Moreover, it may be preferable to identify the ethnic Kromnites in the inscription found by Wiseman (SEG XXII.219) as referring to the well-known Arkadian polis (Shipley 2000: 371-72). Wiseman's identification of the archaeological site in the eastern Corinthia as Kromna can therefore no longer be uncritically accepted (see further Pettegrew 2006).

3. That is, 'artifact density per percent visible' $=$ (artifact density of field $\mathrm{x}$ ) divided by (average density of fields with the same visibility as field $\mathrm{x}$ ).

4. We have chosen this criterion purely for the purposes of clarity and explicitness. Earlier analyses employed other criteria, such as 'natural breaks' in the density data using Jenks/ $\mathrm{K}$-means, and produced highly comparable results.

5. This density figure is calculated by dividing the total number of artifacts counted by the area of each field actually walked, typically one-fifth of the total area of the field (with walker spacing at $10 \mathrm{~m}$ ). Alcock et al. (1994: 138) report that most surveys use density thresholds of 3,000 to 5,000 sherds per ha to define sites; their examples of Archaic to Hellenistic sites have densities of 2,600-15,200 artifacts per ha walked (Alcock et al. 1994: 159), which compares well to the figures in Table 1.

6. Variable visibility does not seem to affect artifact recovery in totally predictable ways. In general, the characteristics of units above $70 \%$ are remarkably regular. The flattening of the various trends at over $70 \%$ visibility is consistent across numerous categories including overall density. This suggests that either our ability to differentiate between units with basically good visibility is relatively limited, or once $70 \%$ of the surface is visible, the effect on our judgment sample begins to diminish. For the complexities of this variable, see also Meyer and Schon 2003: 52-56.

\section{References}

Alcock, S.E.

1993 Graecia Capta: The Landscapes of Roman Greece. Cambridge: Cambridge University Press.

Alcock, S.E., J.F. Cherry and J.L. Davis

1994 Intensive survey, agricultural practice, and the classical landscape of Greece. In I. Morris (ed.), Classical Greece: Ancient Histories and Modern Archaeologies, 137-70. Cambridge: Cambridge University Press.

Ammerman, A.J.

1985 Plow-zone experiments in Calabria, Italy. Journal of Field Archaeology 12: 33-40.

Athanassopoulos, E.F.

2004 Historical archaeology of medieval Mediterranean landscapes. In E. Athanassopoulos and L. Wandsnider (eds.), Mediterranean Archaeological Landscapes: Current Issues, 81 98. Philadelphia: University of Pennsylvania Museum of Archaeology and Anthropology.

Banaji, J.

2001 Agrarian Change in Late Antiquity: Gold, Labour and Aristocratic Dominance. Oxford: Oxford University Press.

Barker, G., C. Mee, W. Cavanagh, R. Schon and J.M. Thompson

2000 Responses to 'The hidden landscape of prehistoric Greece', by J.L. Bintliff, P. Howard and 
A.M. Snodgrass (JMA 12.2, December 1999). Journal of Mediterranean Archaeology 13: 100. 15.

Bees, N.

1936 Morea. In M.T. Houtsma, A.J. Wensinck, E. Levi-Provencal, H.A.R. Gibb and W. Heffenoing (eds.), The Encyclopaedia of Islam III, 566-77. Leiden and London: Brill.

Bintliff, J.

1991 The Roman countryside in central Greece: observations and theories from the Boeotia Survey (1978-1987). In G. Barker and J.A. Lloyd (eds.), Roman Landscapes: Archaeological Survey in the Mediterranean Region, 122-32. London: British School at Rome.

1997 Regional survey, demography, and the rise of complex societies in the ancient Aegean: coreperiphery, neo-Malthusian, and other interpretive models. Journal of Field Archaeology 24: $1-38$.

2000a The concepts of 'site' and 'off-site' archaeology in surface artefact survey. In M. Pasquinucci and F. Trément (eds.), Non-Destructive Techniques Applied to Landscape Archaeology, 200-15. Oxford: Oxbow Books.

$2000 \mathrm{~b}$ Beyond dots on the map: future directions for surface artifact survey in Greece. In J. Bintliff, M. Kuna and N. Venclová (eds.), The Future of Surface Artefact Survey in Europe, 3-20. Sheffield: Sheffield Academic Press.

Bintliff, J., E. Farinetti, P. Howard, K. Sarri and K. Sbonias

2002 Classical farms, hidden prehistoric landscapes and Greek rural survey. A response and an update. Journal of Mediterranean Archaeology 15: 259-65.

Bintliff, J., and P. Howard

1999 Studying needles in haystacks: surface survey and the rural landscape of central Greece in Roman times. Pharos: Journal of the Netherlands Institute in Athens 7: 51-91.

2004 A radical rethink on approaches to surface survey and the rural landscape of Central Greece in Roman Times. In F. Kolb (ed.), Chora und Polis, 43-78. Munich: R. Oldenbourg Verlag.

Bintliff, J., P. Howard and A. Snodgrass

1999 The hidden landscape of prehistoric Greece. Journal of Mediterranean Archaeology 12: 139. 68. 2000a Rejoinder. Journal of Mediterranean Archaeology 13: 116-32.

Bintliff, J., M. Kuna, and N. Venclová (eds.)

2000b The Future of Surface Artefact Survey in Europe. Sheffield: Sheffield Academic Press.

Bintliff, J., and A. Snodgrass

1985 The Cambridge/Bradford Boeotian Expedition: the first four years. Journal of Field Archaeology 12: $123-61$.

1988 Off-site pottery distributions: a regional and interregional perspective. Current Anthropology 29: 506-13.

Blanton, R.E.

2001 Mediterranean myopia. Antiquity 75: 627-29.

Bowden, H., and D. Gill

1997a Roman Methana. In C.B. Mee and H.A. Forbes (eds.), A Rough and Rocky Place: The Landscape and Settlement History of the Methana Peninsula, Greece, 77-83. Liverpool: Liverpool University Press.

1997b Late Roman Methana. In C.B. Mee and H.A. Forbes (eds.), A Rough and Rocky Place: The Landscape and Settlement History of the Methana Peninsula, Greece, 84-91. Liverpool: Liverpool University Press.

Bowden, W., L. Lavan and C. Machado (eds.)

2004 Recent Research on the Late Antique Countryside. Leiden: Brill.

Broneer, $\mathrm{O}$.

1973 Isthmia II: Topography and Architecture. Princeton: American School of Classical Studies at Athens.

Caraher, W.R., and L. Diacopoulos

2004 Less than a village. Paper presented at the 105th annual meeting of the Archaeological Institute of America, San Francisco, California, January 2-5, 2004.

Caraher, W.R., and T.E. Gregory

2006 The fortifications of Mt. Oneion, Corinthia. Hesperia 75.3.

Caraher, W.R., R.S. Moore and D.K. Pettegrew

2005 Final report for the Pyla-Koutsopetria Archaeological Project. Report submitted to the Department of Antiquities, Cyprus, August 2005.

Casey, E.S.

1996 How to get from space to place in a fairly short stretch of time: phenomenological prolegomena. In S. Feld and K.H. Basso (eds.), 
Senses of Place, 13-52. Santa Fe: School of American Research Press.

1997 The Fate of Place. Berkeley: University of California Press.

Chavarría, A., and T. Lewit

2004 Archaeological research on the Late Antique countryside: a bibliographic essay. In W. Bowden, L. Lavan and C. Machado (eds.), Recent Research on the Late Antique Countryside, 3-54. Leiden: Brill.

Cherry, J.F.

1983 Frogs around the pond: perspectives in current archaeological projects. In D.R. Keller and D.W. Rupp (eds.), Archaeological Survey in the Mediterranean Area. British Archaeological Reports International Series 155: 375 416. Oxford: BAR.

1994 Regional survey in the Aegean: 'the new wave' (and after). In P.N. Kardulias (ed.), Beyond the Site: Regional Studies in the Aegean Area, 91-112. Lanham, Maryland: University Press of America.

2002 Vox POPULI: landscape archaeology in Mediterranean Europe. Journal of Roman Archaeology 15: 561-73.

2003 Archaeology beyond the site: regional survey and its future. In J.K. Papadopoulos and R.M. Leventhal (eds.), Theory and Practice in Mediterranean Archaeology: Old World and New World Perspectives, 137-59. Los Angeles: Cotsen Institute of Archaeology.

Cherry, J.F., J.L. Davis, E. Mantzourani and T.M. Whitelaw

1991 The survey methods. In J.F. Cherry, J.L. Davis and E. Mantzourani (eds.), Landscape Archaeology as Long-Term History: Northern Keos in the Cycladic Islands. Monumenta Archaeologica 16: 13-35. Los Angeles: Institute of Archaeology.

Davies, $S$.

2004 The Pylos Regional Archaeological Project, part VI: administration and settlement in Venetian Navarino. Hesperia 73: 59-120.

Davis, J.L.

1991 Contributions to a Mediterranean rural archaeology: historical case studies from the Ottoman Cyclades. Journal of Mediterranean Archaeology 4: 131-216.

(c) The Fund for Mediterranean Archaeology/Equinox Publishing Ltd., 2006
Davis, J.L., S.E. Alcock, J. Bennet, Y.G. Lolos and C.W. Shelmerdine

1997 The Pylos Regional Archaeological Project, part I: overview and the archaeological survey. Hesperia 66: 391-494.

Dunnell, R.C.

1992 The notion 'site'. In J. Rossignol and L. Wandsnider (eds.), Space, Time and Archaeological Landscapes, 21-41. New York: Plenum Press.

Dunnell, R.C., and W.S. Dancey

1983 The siteless survey: a regional scale data collection strategy. In M.B. Schiffer (ed.), Advances in Archaeological Method and Theory 6: 267-87. New York: Academic Press.

Ebert, J.I.

1992 Distributional Archaeology. Albuquerque: University of New Mexico Press.

Engels, D.

1990 Roman Corinth: An Alternative Model for the Classical City. Chicago: University of Chicago Press.

Fentress, E.

2000 What are we counting for? In R. Francovich and H. Patterson (eds.), Extracting Meaning from Ploughsoil Assemblages, 44-52. Oxford: Oxbow Books.

Fentress, E., S. Fontana, R.B. Hitchner and P. Perkins

2004 Accounting for ARS: fineware and sites in Sicily and Africa. In S.E. Alcock and J.F. Cherry (eds.), Side-by-Side Survey: Comparative Regional Studies in the Mediterranean World, 147-62. Oxford: Oxbow Books.

Fentress, E., and P. Perkins

1988 Counting African Red Slip Ware. In A. Mastino (ed.), L'Africa Romana: Atti del V Convegno di studio Sassari, 11-13 dicembre 1987, 205-14. Sassari: Dipartimento di Storia, Università degli Studi di Sassari.

Finlay, G.

1857 The History of Greece under Ottoman and Venetian Domination, 2nd edn. Edinburgh: William Blackwood.

Fish, S.K., and S.A. Kowalewski (eds.)

1990 The Archaeology of Regions: A Case for FullCoverage Survey. Smithsonian Series in Archaeological Inquiry 3. Washington, DC: Smithsonian Institution Press.

Foley, R.

1981a Off-site archaeology: an alternative approach for the short-sited. In I. Hodder, G. Isaac 
and N. Hammond (eds.), Pattern of the Past: Studies in Honour of David Clarke, 157-83. Cambridge: Cambridge University Press.

1981b Off-Site Archaeology and Human Adaptation in Eastern Africa: An Analysis of Regional Artefact Density in the Amboseli, Southern Kenya. British Archaeological Reports International Series 97. Oxford: BAR.

Fowler, H.N.

1932 Corinth and the Corinthia. In H.N. Fowler and R. Stillwell (eds.), Corinth I: Introduction, Topography, Architecture, 18-114. Cambridge, Massachusetts: Harvard University Press.

Francovich, R., and H. Patterson (eds.)

2000 Extracting Meaning from Ploughsoil Assemblages. Oxford: Oxbow Books.

Frangakis, E., and J.M. Wagstaff

1987 Settlement pattern change in the Morea (Peloponnisos) c. AD 1700. Byzantine and Modern Greek Studies 11: 163-92.

Gallant, T.W.

1986 'Background noise' and site definition: a contribution to survey methodology. Journal of Field Archaeology 13: 403-18.

Gebhard, E.R.

1993 The evolution of a pan-Hellenic sanctuary: from archaeology towards history at Isthmia. In N. Marinatos and R. Hägg (eds.), Greek Sanctuaries: New Approaches, 154-77. London: Routledge.

Given, M., and A.B. Knapp (eds.)

2003 The Sydney Cyprus Project: Social Approaches to Regional Archaeological Survey. Monumenta Archaeologica 21. Los Angeles: Cotsen Institute of Archaeology.

Gregory, T.E.

1985 An early Byzantine complex at Akra Sophia near Corinth. Hesperia 54: 411-28.

1993 Isthmia V: The Hexamilion and Fortress. Princeton: American School of Classical Studies at Athens.

2004 Less is better: the quality of ceramic evidence from archaeological survey and practical proposals for low impact survey in a Mediterranean context. In E. Athanassopoulos and L. Wandsnider (eds.), Mediterranean Archaeological Landscapes: Current Issues, 15-36. Philadelphia: University of Pennsylvania Museum of Archaeology and Anthropology.
2006 Contrasting impressions of land use in Early Modern Greece: Kythera and the eastern Korinthia. In S. Davies and J.L. Davies (eds.), Between Venice and Istanbul: Colonial Landscapes and Early Modern Greece c. 1500-1800 $A D$. Hesperia Supplement. Princeton: American School of Classical Studies at Athens.

Hayward, C.L.

2003 Geology of Corinth: the study of a basic resource. In C.K. Williams and N. Bookidis (eds.), Corinth XX: Corinth, The Centenary, 15-42. Princeton: The American School of Classical Studies at Athens.

James, S.A.

2005 An olive press installation from the eastern Korinthia. Poster presented at the 106th Annual Meeting of the Archaeological Institute of America, Boston.

Johnson, I.

2004 Aoristic analysis: seeds of a new approach to mapping archaeological distributions through time. In Stadtarchäologie Wien (ed.), (Enter the Past): the e-way into the four dimensions of cultural heritage. CAA 2003, Computer Applications and Quantitative Methods in Archaeology. Proceedings of the 31 st conference, Vienna, Austria, April 2003. British Archaeological Reports International Series 1227. Oxford: Archaeopress.

Jones, A.H.M.

1964 The Later Roman Empire, 284-602. Norman: University of Oklahoma Press.

Kardulias, P.N., T.E. Gregory and J. Sawmiller

1995 Bronze Age and Late Antique exploitation of an islet in the Saronic Gulf, Greece. Journal of Field Archaeology 22: 3-21.

Kiel, M.

1990 Remarks on the administration of the poll tax (cizye) in the Ottoman Balkans and value of poll tax registers (cizye defterleri) for demographic research. Études Balkaniques 4: 70-104.

1997 The rise and decline of Turkish Boeotia: 15th-19th century. In J. Bintliff (ed.), Recent Developments in the History and Archaeology of Central Greece: Proceedings of the 6th International Boeotian Conference. British Archaeological Reports International Series 666, 315-39. Oxford: BAR. 
1999 The Ottoman imperial registers: central Greece and northern Bulgaria in the 15th19th century, the demographic development of two areas compared. In J. Bintliff and K. Sbonias (eds.), Reconstructing Past Population Trends in Mediterranean Europe (3000 BC-AD 1800), 195-218. Oxford: Oxbow Books.

Kosso, C.

2003 The Archaeology of Public Policy in Late Roman Greece. British Archaeological Reports International Series 1126. Oxford: BAR.

Lock, G., T. Bell and J. Lloyd

1999 Towards a methodology for modelling surface survey data: the Sangro Valley Project. In M. Gillings, D. Mattingly and J. van Dalen (eds.), Geographic Information Systems and Landscape Archaeology, 55-64. Oxford: Oxbow Books.

McGrew, W.W.

1985 Land and Revolution in Modern Greece, 18001881. Kent: Kent State University Press.

Mee, C.B., and H.A. Forbes

1997 Survey methodology. In C.B. Mee and H.A. Forbes (eds.), A Rough and Rocky Place: The Landscape and Settlement History of the Methana Peninsula, Greece, 33-41. Liverpool: Liverpool University Press.

Meyer, $\mathrm{N}$.

2003 Pottery strategy and Chronotypes. In M. Given and A.B. Knapp (eds.), The Sydney Cyprus Survey Project: Social Approaches to Regional Archaeological Survey. Monumenta Archaeologica 21: 14-16. Los Angeles: Cotsen Institute of Archaeology, UCLA.

Meyer, N., and T.E. Gregory

2003 Pottery collection, pottery analysis, and GIS mapping. In M. Given and A.B. Knapp (eds.), The Sydney Cyprus Survey Project: Social Approaches to Regional Archaeological Survey. Monumenta Archaeologica 21: 48-52. Los Angeles: Cotsen Institute of Archaeology, UCLA.

Meyer, N., and R. Schon

2003 Experimental data. In M. Given and A.B. Knapp (eds.), The Sydney Cyprus Survey Project: Social Approaches to Regional Archaeological Survey. Monumenta Archaeologica 21: 52-56. Los Angeles: Cotsen Institute of Archaeology, UCLA.
Millett, M.

1985 Field survey calibration: a contribution. In C. Haselgrove, M. Millett and I. Smith (eds.), Archaeology from the Ploughsoil: Studies in the Collection and Interpretation of Field Survey Data, 31-37. Sheffield: J.R. Collis.

1991 Pottery: population or supply patterns? The Ager Tarraconensis approach. In G. Barker and J.A. Lloyd (eds.), Roman Landscapes: Archaeological Survey in the Mediterranean Region, 18 26. London: British School at Rome.

2000 The comparison of surface and stratified artefact assemblages. In M. Pasquinucci and F. Trement (eds.), Non-Destructive Techniques Applied to Landscape Archaeology, 216-22. Oxford: Oxbow Books.

Morgan, C.

1999 Isthmia VII: The Late Bronze Age Settlement and Early Iron Age Sanctuary. Princeton: American School of Classical Studies at Athens.

Osborne, $\mathrm{R}$.

2001 Counting the cost. Comments on David K. Pettegrew, 'Chasing the classical farmstead'. Journal of Mediterranean Archaeology 14: 212 . 16.

Peacock, D.P.S., and D.F. Williams

1986 Amphorae and the Roman Economy. London: Longman.

Pettegrew, D.K.

2001 Chasing the classical farmstead: assessing the formation and signature of rural settlement in Greek landscape archaeology. Journal of Mediterranean Archaeology 14: 189-209.

2002 Counting and coloring classical farms: a response to Osborne, Foxhall, and Bintliff et al. Journal of Mediterranean Archaeology 15: 267-73.

2004 A Late Roman settlement 'explosion'? The continuity and reuse of sites in the eastern Korinthia. Paper presented at the 105th Annual Meeting of the Archaeological Institute of America, San Francisco.

2006 Corinth on the Isthmus: Studies of the End of an Ancient Landscape. Unpublished PhD dissertation, The Ohio State University.

Pfeiffer, R. (ed.)

1949 Callimachus, I: Fragmenta. Oxford: Clarendon Press. 
Redman, C.L.

1987 Surface collection, sampling, and research design: a retrospective. American Antiquity 52: 249-65.

Robinson, H.S.

1959 Athenian Agora V: Pottery of the Roman Period. Princeton: American School of Classical Studies at Athens.

Roebuck, C.A.

1972 Some aspects of urbanization in Corinth. Hesperia 41: 96-127.

Rothaus, R.M.

1994 Urban space, agricultural space and villas in Late Roman Corinth. In P.N. Doukellis and L.G. Mendoni (eds.), Structures Rurales et Sociétés Antiques, 391-96. Paris: Les Belles Lettres.

2000 Corinth: The First City of Greece. An Urban History of Late Antique Cult and Religion. Leiden: Brill.

Rothaus, R.M., E.G. Reinhardt, T.F. Tartaron and J. Noller

2003 A geoarchaeological approach for understanding prehistoric usage of the coastline of the eastern Korinthia. In K. Foster and R. Laffineur (eds.), Metron: Measuring the Aegean Bronze Age. Aegaeum 24: 37-47. Liège and Austin: Université de Liège and The University of Texas at Austin.

Rutter, J.B.

1983 Some thoughts on the analysis of ceramic data generated by site surveys. In D.R. Keller and D.W. Rupp (eds.), Archaeological Survey in the Mediterranean Area. British Archaeological Reports International Series 155: 13742. Oxford: BAR.

Sakellariou, M., and N. Faraklas

1971 Korinthia-Cleonaea. Archaies Hellenikes Poleis 3. Athens: Athens Center of Ekistics.

Salmon, J.B.

1984 Wealthy Corinth: A History of the City to 338 BC. Oxford: Clarendon Press.

Sanders, G.D.R.

2000 New relative and absolute chronologies for 9th to 13th century glazed wares at Corinth: methodology and social conclusions. In K. Belke, F. Hild, J. Koder and P. Soustal (eds.), Byzanz als Raum: zu Methoden und Inhalten der historischen Geographie des östlichen Mittelmeerraumes,
153-73. Vienna: Österreichischen Akademie der Wissenschaften.

Schofield, A.J. (ed.)

1991 Interpreting Artefact Scatters: Contributions to Ploughzone Archaeology. Oxford: Oxbow Books.

Schofield, A.J.

2000 Understanding early medieval pottery distributions. In S. Stoddart (ed.), Landscapes from Antiquity, 109-19. Cambridge: Antiquity Publications.

Schon, R.

2002 Seeding the Landscape: Experimental Contributions to Regional Survey Methodology. Unpublished $\mathrm{PhD}$ dissertation, Bryn Mawr College, Bryn Mawr, PA.

Scranton, R., J.W. Shaw and L. Ibrahim

1978 Kenchreai: Eastern Port of Corinth I: Topography and Architecture. Leiden: Brill.

Shipley, G.

2000 The extent of Spartan territory in the late Classical and Hellenistic periods. Annual of the British School at Athens 95: 367-90.

2002 The survey area in the Hellenistic and Roman Periods. In W. Cavanagh, J. Crouwel, R.W.V. Catling and G. Shipley (eds.), Continuity and Change in a Greek Rural Landscape: The Laconia Survey, Vol 1, 257-337. London: British School at Athens.

Smith, A.T.

2003 The Political Landscape: Constellations of Authority in Early Complex Societies. Berkeley: University of California Press.

Snodgrass, A.

1994 Response: the archaeological aspect. In I. Morris (ed.), Classical Greece: Ancient Histories and Modern Archaeologies, 197-200. Cambridge: Cambridge University Press.

Steadman, N.

1996 Land use and settlement in post-medieval Greece: an interim discussion. In P. Lock and G.D.R. Sanders (eds.), The Archaeology of Medieval Greece, 179-92. Oxford: Oxbow Books.

Sutton, S.B. (ed.)

2000 Contingent Countryside: Settlement, Economy, and Land Use in the Southern Argolid since 1700. Stanford: Stanford University Press. 
Sutton, S.B.

1994 Settlement patterns, settlement perceptions: rethinking the Greek village. In P.N. Kardulias (ed.), Beyond the Site: Regional Studies in the Aegean Area, 313-36. Lanham, Maryland: University Press of America.

Tartaron, T.F., T.E. Gregory, D.J. Pullen, W.R. Caraher, L. Diacopoulos, D. Nakassis, J. Noller, D.K. Pettegrew, J.L. Rife, R. Rothaus and R. Schon

2007 The Eastern Korinthia Archaeological Survey: integrated methods for a dynamic landscape. Hesperia.

Tartaron, T.F., D.J. Pullen and J.E. Noller

2006 Rillenkarren at Vayia: geomorphology and a new class of Early Bronze Age fortified settlement in southern Greece. Antiquity 80: 145-60.

Tartaron, T.F., R.M. Rothaus and D.J. Pullen

2003 Searching for prehistoric Aegean harbors with GIS, geomorphology, and archaeology. Athena Review 3.4: 27-36.

Terrenato, $\mathrm{N}$.

2000a Surface thoughts: future directions in Italian field surveys. In J. Bintliff, M. Kuna and N. Venclová (eds.), The Future of Surface Artifact Survey in Europe, 21-28. Sheffield: Sheffield Academic Press.

2000b The visibility of sites and the interpretation of field survey results: towards an analysis of incomplete distributions. In R. Francovich and H. Patterson (eds.), Extracting Meaning from Ploughsoil Assemblages, 60-71. Oxford: Oxbow Books.

2004 Sample size matters! The paradox of global trends and local surveys. In S.E. Alcock and J.F. Cherry (eds.), Side-by-Side Survey: Comparative Regional Studies in the Mediterranean World, 36-48. Oxford: Oxbow Books.

Thomas, D.H.

1975 Nonsite sampling in archaeology: up the creek without a site? In J.W. Mueller (ed.), Sampling in Archaeology, 61-81. Tuscon: University of Arizona Press.

Thompson, S.

2004 Side-by-side and back-to-front: exploring intra-regional latitudinal and longitudinal comparability in survey data: three case studies from Metaponto, southern Italy. In S.E. Alcock and J.F. Cherry (eds.), Side-by-Side
Survey: Comparative Regional Studies in the Mediterranean World, 65-85. Oxford: Oxbow Books.

Topping, $\mathrm{P}$.

1972 The post-classical documents. In W.A. McDonald and G.R. Rapp Jr. (eds.), The Minnesota Messenia Expedition: Reconstructing a Bronze Age Regional Environment, 64-80. Minneapolis: University of Minnesota Press.

van Andel, T.H., and C. Runnels

1987 Beyond the Acropolis: A Rural Greek Past. Stanford: Stanford University Press.

Van de Velde, P.

2001 An extensive alternative to intensive survey: point sampling in the Riu Mannu Survey Project, Sardinia. Journal of Mediterranean Archaeology 14: 24-52.

Vroom, J.

2003 After Antiquity: Ceramics and Society in the Aegean from the 7th to the 20th Century A.C. A Case Study from Boeotia, Central Greece. Archaeological Studies, Leiden University 10. Leiden: Faculty of Archaeology, Leiden University.

2005 Byzantine to Modern Pottery in the Aegean: An Introduction and Field Guide. Utrecht: Parnassus Press.

Wagstaff, J.M.

1978 War and settlement desertion in Morea, 1685-1830. Transactions of the Institute of British Geographers 3: 295-308.

Ward-Perkins, B.

2000 Land, labour and settlement. In A. Cameron, B. Ward-Perkins and M. Whitby (eds.), The Cambridge Ancient History XIV: Late Antiquity, 315-45. Cambridge: Cambridge University Press.

Wilkinson, T.J.

1982 The definition of ancient manured zones by means of extensive sherd-sampling techniques. Journal of Field Archaeology 9: 223-33.

Williams, C.K.

1984 The early urbanization of Corinth. Annuario della Scuola archeologica di Atene 60 n.s. 44 [1982]: 9-20.

Williams, C.K., and N. Bookidis (eds.)

2003 Corinth XX: Corinth, the Centenary: 18961996. Princeton: The American School of Classical Studies at Athens. 
Wiseman, J.R.

1963 A trans-Isthmian fortification wall. Hesperia 32: 248-75.

1978 The Land of the Ancient Corinthians. Studies in Mediterranean Archaeology 50. Göteborg: Paul Åströms Förlag.
Wright, J.C., J.F. Cherry, J.L. Davis, E. Mantzourani, S.B. Sutton and R.F. Sutton, Jr.

1990 The Nemea Valley Archaeological Project: a preliminary report. Hesperia 59: 579-659.

Zarinebaf, F., J. Bennet and J. Davies

2005 A Historical and Economic Geography of Ottoman Greece: The Southwestern Morea in the 18th Century. Hesperia Supplement 34. Princeton: American School of Classical Studies at Athens. 